\title{
REGULARIZACIÓN DE DERECHOS CONSUETUDINARIOS DE AGUAS: CRÍTICA A LA JURISPRUDENCIA VACILANTE DE LA CORTE SUPREMA
}

\author{
Alejandro Vergara Blanco \\ Pontificia Universidad Católica de Chile
}

\begin{abstract}
RESUMEN: Este artículo revisa el régimen jurídico que ampara los usos y derechos consuetudinarios de aguas, así como su formalización, para luego mostrar el sorprendente giro jurisprudencial que a partir de diciembre de 2014 realizó la Tercera Sala de la Corte Suprema respecto de la regularización de tales derechos. Se describen las consecuencias de este giro y se desarrollan argumentos de fondo sobre la materia. Se critica, además, el vacilante comportamiento jurisprudencial durante los últimos años, caracterizado por constantes zigzagueos tanto de los ministros como de la sala. A partir de este estudio de caso, se ofrecen algunas reflexiones sobre política pública jurisdiccional, certeza jurídica y dispersión jurisprudencial.

Palabras Clave: derechos de agua, Código de Aguas, regulación de derechos, jurisprudencia, Corte Suprema, incerteza jurídica, dispersión jurisprudencial.
\end{abstract}

RECIBIDO: abril 2018; ACEPTADO: julio 2018.

Alejandro Vergara Blanco. Profesor titular de derecho administrativo y de teoría del derecho de la Pontificia Universidad Católica de Chile. Investigador del Centro de Derecho y Gestión de Aguas y director del Programa de Derecho Administrativo Económico, ambos de la misma universidad. Email: alvergar@uc.cl.

El autor desea consignar sus agradecimientos al editor por sus numerosas sugerencias y a los árbitros anónimos de Estudios Públicos, en especial a uno de ellos, quien propuso la sistematización definitiva del artículo. 


\section{REGULARIZING CUSTOMARY WATER RIGHTS: A CRITICISM OF THE UNSETTLED JURISPRUDENCE OF THE SUPREME COURT}

ABSTRACT: This article reviews the legal regime covering customary water rights and uses and their formalization, then goes on to show the surprising jurisprudential turn taken by the Third Chamber of the Supreme Court since December 2014 with regard to the regularization of these customary rights. It describes the consequences of this shift and advances arguments dealing with the underlying issues. It also criticizes the unsettled approach to jurisprudence in recent years, with constant changes of direction by both ministers and the court. This case study is used as a basis for some reflections on public policy as it relates to jurisdiction, on legal certainty and on dispersed jurisprudence.

KeYworDs: water rights, Water Code, regulation of rights, jurisprudence, Supreme Court, legal uncertainty, dispersed jurisprudence. ReCEIVED: April 2018; ACCEPTED: July 2018.

\section{INTRODUCCIÓN}

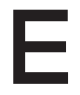

ste trabajo argumenta, en materia de regularización de derechos consuetudinarios, (i) que la Corte Suprema desde 2014 ha reemplazado la jurisprudencia uniforme que existía anteriormente por una jurisprudencia vacilante - repitiendo en algunos casos su criterio previo a 2014 y en otros rechazándolo-; (ii) que desde un punto de vista jurídico el nuevo criterio jurisprudencial que supuestamente sólo intenta reinterpretar las normas atinentes más bien las quebranta, dado que el derecho vigente consagra un explícito reconocimiento de los derechos de aguas de origen costumbrista y que no es posible racionalmente extraer de sus términos o factum las exigencias que inventa la nueva jurisprudencia; y (iii) que la jurisprudencia actual, y la conducta de la Corte Suprema en esta materia, crea una doble incertidumbre: tanto por este nuevo criterio de fondo en la materia, que deja heridas a esas titularidades consuetudinarias, como por la conducta vacilante que resulta de los constantes zigzagueos de la Corte y de algunos de los ministros.

La regularización de los derechos consuetudinarios de aguas es una temática socialmente relevante, dado que la mayoría de los derechos de aprovechamiento de aguas en Chile tiene origen costumbrista, los que 
están en manos de agricultores, indígenas y de una variada gama de usuarios rurales de aguas. ${ }^{1}$

El tema de fondo que analizo en este trabajo se configura a partir del siguiente factum o hipótesis de hecho típica: centenares de agricultores, indígenas u otros usuarios de aguas han gozado de una protección constitucional de sus usos y derechos, aun cuando tales derechos tienen un origen consuetudinario (esto es, en un uso muy antiguo o ancestral); ello, en virtud de una disposición legal de 1979 (en estricto rigor, de un decreto ley), que estableció una presunción de propiedad sobre esos usos y derechos consuetudinarios, lo que fue reafirmado por la Constitución de 1980 y el Código de Aguas de 1981. Lo más relevante es que tales usuarios de aguas no han tenido nunca que solicitarle a la autoridad administrativa la constitución de su título, pues tales títulos han

${ }^{1}$ Se ha estimado que a la fecha de entrada en vigencia del Código de Aguas, en 1981, una cantidad cercana al 70 por ciento de los usos efectivos de aguas correspondía a usos consuetudinarios, los cuales carecían de títulos inscritos. En Banco Mundial, Diagnóstico de la gestión de los recursos hídricos (Santiago: Documento del Banco Mundial, Departamento de Medio Ambiente y Desarrollo Sostenible Región para América Latina y el Caribe, 2011), que es el informe más actualizado sobre la situación de los recursos hídricos, se consigna que sería el 80 por ciento. Este documento señala en la página 48: "La DGA estima que de unos 350.000 derechos de aguas legítimos solamente alrededor de 70.000 están inscritos en el Registro de Propiedad de Derechos de Aguas del Conservador de Bienes Raíces (20 por ciento), lo que demuestra un desfase importante entre el régimen catastral y la realidad".

De una consulta realizada por transparencia a la Dirección General de Aguas sobre la existencia de un porcentaje o información cuantificada respecto al número de derechos de aprovechamiento no inscritos, hemos obtenido como respuesta, el día 27 de abril de 2018: "De acuerdo al artículo 122 del Código de Aguas, que establece el catastro público de aguas como un registro público de derechos de aprovechamiento de agua no inscritos en los registros conservadores de bienes raíces, susceptibles de regularización en virtud del artículo $2^{\circ}$ transitorio del Código, no se ha implementado el señalado registro, así como no se le menciona en el DS 1.220 de 1998 que aprueba el Reglamento del Catastro Público de Aguas”. Realizada la misma consulta a la Comisión Nacional de Riego (CNR), nos informó el día 25 de abril: “(...) no se dispone de información sobre dicha estimación o cuantificación de derechos de aguas no inscritos", remitiéndonos información sobre diagnósticos realizados por la propia CNR en algunas cuencas y territorios específicos. Finalmente, esta misma consulta se dirigió a la Confederación de Canalistas de Chile, obteniendo la siguiente respuesta, el día 30 de mayo de 2018: "Se han realizado encuestas parciales, a nivel de muestreo, llegando a la conclusión que, de los actuales derechos de aprovechamiento de aguas, un valor superior al 45 por ciento no se encontrarían inscritos en los conservadores de bienes raíces". 
surgido del reconocimiento legal del uso consuetudinario. El legislador decidió además someter tales usos y derechos a un régimen registral, disponiendo el procedimiento destinado a reconocerlos, el cual se denomina "regularización", circunstancia que en realidad es una adecuación a la nueva normativa nacida en los años 1979 y 1980, con lo cual no se crean dichos derechos, sino que se reconocen. Por diversas razones prácticas, es conveniente regularizar o formalizar esos títulos, y la legislación provee de un mecanismo de regularización al efecto; pero la ley no ha establecido plazo alguno para que esos usuarios regularicen sus títulos, y el resultado práctico es que aún hoy existen miles de titulares de derechos de origen consuetudinario, cuyo uso del agua comenzó en fechas anteriores a las señaladas (1979, 1980 y 1981), en que sus sucesores han seguido usando tales aguas amparados en esa poderosa presunción legal, sin regularizar sus títulos. ${ }^{2}$

Durante muchos años, cada vez que un titular de esos derechos solicitaba su regularización, ésta se tramitaba en un procedimiento pacífico, con intervención de la administración y de los tribunales. De ese modo se regularizaron centenares de derechos de aguas. Pero en diciembre de 2014 todo cambió, específicamente a partir del giro jurisprudencial de que doy cuenta en este escrito. Esta nueva tendencia afecta gravemente los derechos de las personas que son titulares de estos derechos así reconocidos, unido a las costosas tramitaciones y a la usualmente lenta respuesta de la administración burocrática.

También examino, a partir de argumentos de dogmática jurídica (esto es, sobre la base del análisis del derecho vigente), las posiciones que la Corte Suprema - de una manera dividida, pero mayoritaria - ha venido sosteniendo desde fines de 2014 en materia de regularización de derechos de aprovechamiento de aguas, momento a partir del cual protagonizó un brusco giro respecto de la jurisprudencia anterior. Po-

${ }^{2}$ El proyecto de modificación del Código de Aguas que desde 2011 se tramita en el Congreso Nacional (Boletín 7543-12) intentó introducir una caducidad respecto de los derechos que no se regularicen en un plazo determinado, lo que ha sido muy polémico, por la precarización a que deja sometidos tales derechos. Véase la crítica y denuncia de Alejandro Vergara, "Modificación al Código de Aguas: desprotección y caducidad de derechos ancestrales", en, del mismo autor, Derecho de aguas: Identidad y transformaciones (Santiago: Ediciones UC, 2017), 255-257. 
dremos observar que, desde esa fecha y hasta agosto $^{3}$ de 2018 , se ha producido una situación jurisprudencial zigzagueante, consecuencia de la conducta de algunos ministros y abogados integrantes de la Tercera Sala de la Corte Suprema. Se ha producido así una alta inestabilidad en las decisiones, con frecuentes contradicciones de los votos de un mismo ministro o abogado integrante entre causas exactamente iguales, sin existir ninguna razón aparente que explique esos cambios intempestivos de posición. No califico en este trabajo las consecuencias institucionales o disciplinarias que podría tener esta conducta vacilante, pues va más allá de mi objetivo; sin perjuicio de mis reflexiones finales sobre el valor de la estabilidad jurisprudencial.

\section{EL RECONOCIMIENTO DE LOS USOS COSTUMBRISTAS DE AGUAS}

\subsection{Un derecho consuetudinario de aguas en un país hiperlegalista y de acendrado centralismo administrativo}

El reconocimiento de los derechos de origen consuetudinario en los sistemas jurídicos modernos es uno de los mayores homenajes a la libertad de los ciudadanos y una excepción al monopolio del legislador. ${ }^{4}$ Es una suerte de expansión de la libertad individual y colectiva al reconocer cierta autogestión normativa de la sociedad. En nuestro país son pocos los ejemplos; un caso paradigmático es el de los derechos de aguas de origen consuetudinario, los que fueron reconocidos como tales por el legislador en 1979.

Los derechos consuetudinarios de aguas (usualmente de agricultores, indígenas, industrias forestales y frutícolas, vinícolas y otros

${ }^{3}$ Si bien el presente artículo fue aceptado en julio de 2018, durante su proceso de edición, el autor incorporó información hasta agosto del mismo año. (N. del E.)

${ }^{4} \mathrm{El}$ reconocimiento de la costumbre ha sido excepcional, dado que el sistema de fuentes en Chile ha sido legalista. Una muestra de ello es el artículo 2 del Código Civil, el cual señala: "La costumbre no constituye derecho sino en los casos en que la ley se remite a ella", lo que equivale a decir que sólo la ley constituye derecho. Pero esa descripción del fenómeno de las fuentes del derecho realizado a mediados del siglo XIX ha variado significativamente, no sólo por las variadas remisiones legislativas a la costumbre, sino porque también, a partir de la propia jurisprudencia, hoy podemos considerar que la ley ha perdido ese monopolio a manos de los principios (que son, en realidad, un trasunto de la costumbre). El tema de la conexión de la costumbre con los principios corresponde a la teoría del derecho y no lo abordo en este sitio. 
usuarios rurales) surgen como tales a partir de un uso costumbrista o ancestral y son reconocidos por ley (art. 7 DL 2.603 de 1979) y garantizados por la Constitución (art. $19 \mathrm{n} .^{\circ} 24$ inciso final). Estas dos reglas son la base de la existencia de tales derechos, a las cuales cabe agregar el artículo 2 transitorio del Código de Aguas (art. 2T, en adelante CA), que contempla una regulación del procedimiento atinente, cuyo objetivo es la "regularización" o formalización de los títulos de derechos de aguas. Existen pocas reglas más importantes que ésta en la regulación de los usos consuetudinarios, pues son la base de su existencia y reconocimiento. ${ }^{5}$

Estos derechos nacen de un uso costumbrista; de un factum que origina un derecho no registral (informal, si se quiere), pero de titularidades reconocidas y plenamente protegidas. Su existencia y ejercicio práctico está fuera de toda duda; es cosa de mirar la geografía física y humana de nuestro país. Lo único que falta respecto de esos derechos es su "formalización", esto es, su escrituración y registro; o su "perfeccionamiento", incorporando a sus títulos el detalle de las características esenciales de todo derecho formalizado de aguas: caudal, lugar de extracción o naturaleza (ya sea de uso consuntivo o no consuntivo; de ejercicio eventual o permanente; superficial o subterráneo; en fin, de uso continuo, discontinuo o alternado). En ningún caso la falta de tales formalidades pone en cuestión ni la existencia ni tampoco el legítimo ejercicio de esos derechos. De ahí que un título informal de aguas (costumbrista) sea entonces tan legítimo, garantizado y protegido como uno formalizado. La razón es muy simple: los derechos consuetudinarios existen socialmente antes de su regulación legal, la cual sólo reconoce y somete esa realidad a una nueva formalidad con el objetivo de dar mayor certeza, certidumbre y seguridad.

Los usos efectivos de aguas como derechos adquieren legitimidad por el reconocimiento que les brinda el citado artículo 7 DL 2.603 de 1979, que establece dos presunciones de titularidad de derecho de aguas a quien utilizaba efectivamente las aguas en la fecha de esa norma. Pero

${ }^{5}$ El tema de los derechos consuetudinarios fue objeto hace veinte años de un artículo en esta misma revista al que cabe remitirse, pues ahí se explica su estatuto jurídico. Ver Alejandro Vergara, "Estatuto jurídico, tipología y problemas actuales de los derechos de aprovechamiento de aguas. En especial, de su regularización y catastro", Estudios Públicos 69 (1998): 155-205. 
eso no cierra el proceso de consolidación de esos derechos consuetudinarios, sino que es conveniente dotarlos de un título formal e inscribirlos en los registros correspondientes. Existe para ello una triple fase de reconocimiento, subsistencia y ajustes, como se ha dicho en doctrina. ${ }^{6}$

\subsection{La regularización de los derechos reconocidos y sus requisitos}

La "regularización", entonces, resulta ser una herramienta procedimental de ajuste para estos derechos. Los requisitos que señala el artículo 2 transitorio del CA para obtener tal regularización son los siguientes:

i) que el ejercicio de este derecho (el uso efectivo de las aguas en un terreno específico) se debe haber estado produciendo a la fecha de entrada en vigor del CA (es decir, el 29 de octubre de 1981);

ii) que se hayan cumplido al menos cinco años ininterrumpidos de ese uso efectivo del agua, ${ }^{7} \mathrm{y}$

iii) que la utilización se haya efectuado libre de clandestinidad o violencia y sin reconocer dominio ajeno.

Entonces, entre los requisitos para la regularización de los derechos de aguas expuestos es esencial el uso efectivo del agua, el que está

\footnotetext{
${ }^{6}$ Sobre el tema de la regularización de derechos de aguas existe una literatura especializada, en la que nunca apareció la argumentación de la nueva línea jurisprudencial. Véanse los trabajos de Alejandro Vergara, "Estatuto jurídico"; Alejandro Vergara, Derecho de aguas (Santiago: Editorial Jurídica de Chile, 1998); Christian Neumann, "Del procedimiento especial de regularización de derechos de aprovechamiento de aguas conforme al artículo $2^{\circ}$ transitorio del Código de Aguas", Revista de Derecho Administrativo Económico 2, n. ${ }^{\circ}$ (2000): 211-246; Gonzalo Muñoz, "Problemas que plantean las regularizaciones de derechos de aprovechamiento de aguas", Revista de Derecho Administrativo Económico 3, n. ${ }^{\circ} 2$ (2001): 565-576; Gonzalo Muñoz, "Regularización de derechos de aprovechamiento de aguas", en Código de Aguas Comentado, editado por Alejandro Vergara (Santiago: Abeledo Perrot, 2011), 1165-1188; en especial la tesis doctoral de Daniela Rivera, Usos y derechos consuetudinarios de aguas. Su reconocimiento, subsistencia y ajuste (Santiago: Thomson Reuters, 2013), 277-278; y Alejandro Vergara, Crisis institucional del agua. Descripción del modelo jurídico, crítica a la burocracia y necesidad de tribunales especiales (Santiago: Ediciones UC, 2015), 46-49.

${ }^{7}$ Esta exigencia originó varias discusiones doctrinales y jurisprudenciales. Las analizo brevemente más adelante (sección 1.5). Pareciera que es motivo de pocas controversias en la actualidad; ver al respecto los análisis que ofrecen Gonzalo $\mathrm{Mu}$ ñoz, "Problemas", 568-569, y Neumann, "Del procedimiento", 226.
} 
vinculado a un hito cronológico: la entrada en vigor del CA. La ley no establece otras limitaciones o requisitos. Así:

i) no existe un plazo para solicitar la regularización, de lo que se deriva que se puede realizar en cualquier tiempo, mientras una nueva ley no diga lo contrario, y

ii) no establece la ley exigencia alguna respecto de los adquirentes de estos derechos de aguas, en su condición de derechos reales, por lo que en tal aspecto se regirán por las reglas del Código de Aguas y, supletoriamente, por el Código Civil (materia en la cual este último código es legítimamente supletorio, dados los términos del artículo 6 del CA).

\subsection{La posesión de todo derecho real y la suma de posesiones para los efectos de solicitar la regularización por adquirentes posteriores al año 1981}

El tema de la suma de posesiones, sin embargo, ha devenido neurálgico, y en torno a éste se ha generado el cambio jurisprudencial que comento en este trabajo.

Entonces, el primer y esencial requisito para toda regularización es el uso efectivo de las aguas a la fecha de entrada en vigor del CA (29 de octubre de 1981). Al respecto, dada la calidad de derecho real de todo derecho de aguas (art. $6 \mathrm{CA}$ ), son estos derechos aquellos poseídos de manera ficta por sus titulares, y por todos los sucesores de la titularidad, desde esa fecha hasta la actualidad; en otras palabras, no son las aguas las jurídicamente poseídas, sino el derecho. Además, el uso efectivo del agua a que se refiere la ley no es algo que se produzca en términos personales por el titular de ese derecho (como si tuviese que tocar el agua con sus manos), sino que el uso efectivo se produce en un terreno, inmueble o bien raíz específico, en relación al cual tiene lugar el reconocimiento de este derecho, ello derivado de su calidad de derecho real (art. 6 CA) y no personal. Para comprender este factum basta una lectura de la regla de oro de estos derechos: el artículo 7 DL 2.603 de 1979, que dispone:

Se presumirá dueño de derecho de aprovechamiento a quien lo sea del inmueble que se encuentre actualmente utilizando dichos derechos. 
En caso de no ser aplicable la norma precedente, se presumirá que es titular del derecho de aprovechamiento quien se encuentre actualmente haciendo uso efectivo del agua.

Tanto la posesión de un derecho como el derecho mismo se pueden transferir a nuevos titulares, los cuales pasarán a ser titulares del derecho así reconocido y en el momento que lo deseen (pues no hay una fecha que la ley haya establecido para ello) podrán solicitar la regularización de esos derechos. En efecto, cualquier titular actual del derecho consuetudinario puede solicitar su regularización, en el tiempo que desee, debiendo probar que en esa lejana fecha existía un uso efectivo del agua $\mathrm{y}$, además, que ese uso se mantiene en la actualidad.

El derecho de aguas así reconocido en 1981, y materia de posesión por sus antiguos titulares, se puede transferir o transmitir y a este cómputo se puede agregar la posesión del derecho (y uso del agua) de los antecesores en su titularidad, aplicando la figura de la suma de posesiones, que permite agregar el tiempo de posesión del antecesor, siguiendo la regla del artículo 717 inciso 2 del Código Civil, que señala:

Podrá agregarse (...) a la posesión propia la de una serie no interrumpida de antecesores.

O sea, una cadena o sumatoria de posesiones que es admitida pero que debe ser probada.

\subsection{Coherencia del modelo regulatorio de los usos consuetudinarios de aguas con la influyente teoría de la posesión de Savigny}

Lo más notorio de esta regulación de los usos consuetudinarios de aguas es el valor que se les otorga tanto a los usos como a la posesión por la vía de la costumbre. Además, cabe destacar la protección que se les presta a tales derechos, reconociéndolos y considerándolos plenos por sí mismos, aun cuando no estén regularizados.

Al respecto, podemos recalcar la coherencia de tal regulación con lo que a inicios del siglo XIX postulaba Savigny, quien, en su primera obra jurídica significativa dedicada precisamente a la posesión, ${ }^{8}$ adopta

${ }^{8}$ Karl Friedrich von Savigny, Das Recht des Besitzes. Eine Civilistiche Abhandlung (1803) [El derecho de posesión. Una monografía civilista], la que alcanzó seis ediciones, siendo la sexta, de 1865 , con reimpresiones recientes. 
la posición de un jurista "realista" (no formalista), apegado a los hechos, a la práctica de los usos y costumbres legítimos, tesis que ha influido ampliamente en la construcción de la dogmática de los derechos reales. ${ }^{9}$ Él observa que la posesión es la tenencia de una cosa, sin perjuicio de lo cual tiene un contenido jurídico pleno; ese fenómeno de tenencia de la posesión es idéntico al problema jurídico actual de la posesión del título de los usos consuetudinarios de aguas reconocidos en 1979.

¿Cómo enfrenta Savigny esta tenencia, ese uso llamado posesión? La separa jurídicamente de la propiedad y la considera en sí misma como un derecho, la cual: (i) está conectada a la propiedad, pues quien posee puede llegar a ser propietario por la vía de la usucapión (prescripción), y (ii) puede ser defendida y garantizada de la molestia de terceros por sí misma, mediante acciones posesorias.

Si observamos el caso de los usos consuetudinarios de aguas, descubriremos que tanto el artículo 7 DL 2.603 de 1979, como el artículo 19 n. ${ }^{\circ} 24$ inciso final de la Constitución de 1980 y el artículo 181 del Código de Aguas de 1981 protegen esos usos como tales, como hechos, como factum, dándoles la misma garantía que los derechos de propiedad, sin serlo; esto es, protegen una tenencia a la Savigny: sin necesidad de obligar a sus titulares a formalizarlos, inscribirlos o de llegar a ser como otro tipo de derechos de aguas que nacen formalizados (como es el caso de los derechos de aguas constituidos por concesión o acto de autoridad, según señala el artículo 22 del Código de Aguas). Los derechos de agua consuetudinarios, entonces, nacen "des-formalizados" y pueden continuar su vida jurídica en tales condiciones sin riesgo (salvo que las formalidades lleguen a ser elementos más relevantes que la esencia de un derecho, lo que no es el caso actual en nuestra legislación).

\subsection{El cómputo del plazo de cinco años ininterrumpidos de uso efectivo del agua}

El cómputo del plazo de cinco años ininterrumpidos de uso efectivo del agua es un requisito que merece destacarse también. Éste puede observarse en la jurisprudencia, la doctrina y en su contexto legislativo,

${ }^{9}$ Ver Arturo Alessandri Rodríguez y Manuel Somarriva Undurraga, Curso de derecho civil. Los bienes y los derechos reales (Santiago: Editorial Nascimento, 1974), 445-448. 
pues es conexo al problema que reviso $\mathrm{y}$, en algunas ocasiones, una misma sentencia revisa tanto este requisito como el que concierne al uso efectivo de las aguas.

\subsubsection{A nivel jurisprudencial}

El cómputo de este plazo de cinco años fue abordado de diversas maneras, entre las cuales cabe mencionar los siguientes criterios jurisprudenciales: (i) Se ha dicho que el referido plazo de cinco años debe contarse desde la fecha en que comenzó el uso de las aguas y que debía encontrarse cumplido a la fecha de entrada en vigencia del Código de $1981 .{ }^{10}$ (ii) También se ha señalado que dicho plazo simplemente se cuenta desde la fecha en que hubiera comenzado a producirse el uso respectivo $^{11}$ (aquí no se requiere que los cinco años se encuentren cumplidos el 29 de octubre de 1981, como ocurre en el caso anterior). (iii) Asimismo, se ha fallado que dicho plazo debe contarse desde la fecha de entrada en vigencia del Código de $1981 .{ }^{12}$ (iv) Se ha dicho que este plazo debe encontrarse cumplido a la fecha de la respectiva solicitud de regularización. ${ }^{13}$ (v) Finalmente, se ha señalado que dicho plazo debe haberse iniciado antes del 29 de octubre de $1981 .{ }^{14}$

${ }^{10}$ En varios casos la Corte Suprema se ha pronunciado en tal sentido: "Sociedad Agrícola y Ganadera El Tranque Limitada con Asociación de Canalistas del Embalse de Recoleta" (1995); "Sucesión Franco Ahumada con Junta de Vigilancia Río Huasco y otro" (1997); "Sociedad Transroden Ltda. y otra con Sociedad de Inversiones Myne Ltda." (2001); "Comunidad Atacameña Toconce con Essan S.A." (2004); "Sociedad Agrícola El Sobrante Limitada con Comunidad de Aguas Canal Chimba Sur" (2004); "Pacic con Comunidad Indígena Aymara Chusmiza y Usmagama" (2008). Esta jurisprudencia no la analizo en este trabajo (de ahí que no está colacionada en el Anexo) pues se refiere a otro de los requisitos de la regularización: el cómputo de los cinco años.

11 En caso "Sociedad Legal Minera Santa Dorila Primera de Las Arenitas"

12 En caso "Asecio con Junta de Vigilancia del Río Tinguiririca y otros" (2001).

${ }^{13}$ Se han pronunciado en tal sentido: "Acuña con Gallardo" (1992); "Tunis y otro con Sociedad El Trapiche S.A.” (1994); "Pérez Llona, Gonzalo y Ricardo" (1996).

${ }^{14}$ Caso "Comunidad de Aguas del Canal Tomé Alto y Otros con Sociedad Jaime Prohens y Compañía Limitada” (1998). 


\subsubsection{A nivel doctrinal}

Esta discusión también se produjo en el ámbito doctrinario, del que pueden mencionarse las siguientes posiciones: (i) Se ha señalado que el artículo 2 transitorio del CA establece que la fecha de entrada en vigencia del Código de 1981 marca el último plazo a partir del cual debió iniciarse el uso de las aguas. ${ }^{15}$ ii) Se considera que el plazo de cinco años de uso ininterrumpido debe ser contado hacia atrás, desde la entrada en vigencia del Código de $1981{ }^{16}$

Ahora bien, la Dirección General de Aguas (DGA), en un acto de orden interno, señala que el derecho de aprovechamiento debe haber estado siendo utilizado cinco años antes de entrar en vigencia el CA de 1981; es decir, del 29 de octubre de 1976 hacia atrás. ${ }^{17}$ A pesar de que estas últimas expresiones no parecen del todo claras y precisas, se entiende que la opinión de la autoridad administrativa en esta materia es que el plazo de cinco años requerido en este procedimiento regularizador debe encontrarse cumplido al 29 de octubre de 1981, por lo que el uso respectivo debió haberse iniciado, a más tardar, el 29 de octubre de 1976.

\subsubsection{Necesaria vinculación del artículo 2 transitorio del CA con el artículo 7 DL 2.603 para resolver situación del plazo}

Puede percibirse que en cuanto a este aspecto del cómputo del plazo se han manifestado, entonces, tres posibilidades interpretativas: (i) El uso de cinco años exigido al regularizador debe encontrarse cumplido al año 1981, más específicamente, a la fecha de entrada en vigencia del Código de Aguas de 1981, por lo que se cuenta desde dicho año hacia atrás. (ii) El uso de cinco años exigido al regularizador puede comenzar con posterioridad o a partir de la entrada en vigencia del Código de Aguas de 1981. O (iii), el uso exigido al regularizador debe ser actual a la época de entrada en vigencia del Código de Aguas de 1981; es decir, debe haber comenzado con anterioridad a ello y estar sucediendo

${ }^{15}$ Gonzalo Muñoz, "Problemas", 568-569.

${ }^{16}$ Neumann, "Del procedimiento", 226.

${ }^{17}$ Dirección General de Aguas. Manual de Normas y Procedimientos para la Administración de Recursos Hídricos. S. I. T. n. ${ }^{\circ} 156$ (Ministerio de Obras Públicas de Chile, 2008), 126. 
a esa fecha, y completar, en lo que corresponda, el plazo de cinco años hacia delante.

Teniendo en consideración el estatuto jurídico completo de la regularización de los usos consuetudinarios, diremos que, a nuestro juicio, ${ }^{18}$ es esta última la opción interpretativa que cabe aplicar en materia de cómputo del plazo de cinco años establecido en el artículo 2 transitorio del CA. Sin perjuicio de ello, cabe reconocer que la primera de las alternativas enunciadas cuenta con el beneplácito de la generalidad de la jurisprudencia y de la propia DGA, y, además, parece una opción racional. Ahora bien, la segunda opción no resiste mayor análisis, ya que resulta absolutamente incorrecta y desajustada, pues el objeto de los procedimientos regularizadores son los usos y derechos preexistentes al Código de Aguas de 1981 y no los que comiencen a ejercerse con posterioridad al mismo.

El tercer criterio enunciado es el que mejor nos permite encuadrar la problemática en la normativa aplicable al caso. Como se ve, además del artículo 2 transitorio del CA, este tema debe vincularse obligatoriamente con el artículo 7 DL 2.603, el cual contiene la esencia, la base sustantiva del reconocimiento a los usos consuetudinarios, y dicha disposición no señala ni exige plazo alguno al uso de las aguas. Tal plazo vino sólo a ser establecido por la norma transitoria en comento, la cual reguló y estableció la vía procedimental del reconocimiento consagrado en el artículo 7 DL 2.603.

Así, la idea matriz es que los usos efectivos de las aguas que se hubieren iniciado con anterioridad al Código de 1981 son reconocidos como derechos. Si los titulares desean regularizar tales derechos deben reunir, como mínimo, un plazo de cinco años de uso, pero, debido a que el referido artículo 7 DL 2.603 no exige plazo alguno, no procede exigir que tal plazo esté totalmente cumplido al año 1981, sino que lo que resulta obligatorio es que el uso en cuestión se haya iniciado antes de tal fecha. En este caso, si a la época de entrada en vigencia del Código de Aguas de 1981 falta un período para completar el plazo de cinco años, el correspondiente uso podrá continuarse ejerciendo con posterioridad a ello hasta cumplir el requisito aludido, y poder impetrar, por tanto, la regularización e inscripción del derecho como tal.

${ }^{18}$ Coincidiendo en este sentido con lo expresado por Gonzalo Muñoz, "Problemas", 568 . 


\subsection{La regularización está sujeta a un régimen jurídico permanente y no temporal}

Ya está dicho que las reglas sustanciales aplicables a la materia de la regularización de derechos de aguas consuetudinarios son los Arts. 7 DL 2.603 de 1979 y 2 transitorio del CA. Ambas normas son el trasunto de la aceptación de la costumbre en la materia (siguiendo el criterio del artículo 2 del Código Civil) y constituyen un régimen jurídico permanente $\mathrm{y}$, en ningún caso, dados los términos tan enfáticos y asertivos de ambas disposiciones legales, puede llegar a postularse que se trataría de un régimen jurídico temporal; ello por el dato más básico: el enunciado de tales normas no fija período temporal alguno para ejercer el derecho (o la libertad) de solicitar la regularización de los derechos de aguas consuetudinarios.

Dos aspectos podrían llamar a dudas: por una parte, la vigencia actual del artículo 7 DL 2.603 de 1979 y, por otra, el carácter "transitorio" del artículo 2 transitorio del CA (que se suele confundir con las leyes "temporales").

\subsubsection{La actual vigencia del artículo 7 DL 2.603 de 1979}

El DL 2.603 de 1979 es la regla vigente que de modo sustantivo reconoce los derechos consuetudinarios. Como norma ordinaria y permanente, ninguna duda puede caber con respecto a su actual vigencia; ello, por varias razones: ${ }^{19}$

i) Porque el artículo $181 \mathrm{CA}$, relativo al amparo de los derechos de aguas, vigente desde 1981, contiene una expresa remisión al referido artículo 7 DL 2.603 de 1979, precisamente reconociendo la fuerza de su "presunción de dueño" de derechos de aprovechamiento de aguas. Dice tal artículo 181 inciso $1 \mathrm{CA}$ :

El titular de un derecho de aprovechamiento o quien goce de la presunción a que se refiere el artículo $7^{\circ}$ del decreto ley $\mathrm{N}^{\circ} 2.603$, de 1979, que estimare estar siendo perjudicado en el aprovecha-

${ }^{19}$ Lo que también se aplica a otros artículos de tal DL, como sus artículos 4 y 6. Ver Dictamen n. 14.716 (1992). También, Alejandro Vergara, "Reconocimiento de usos consuetudinarios de aguas", en Código de Aguas comentado (Santiago: Abeledo Perrot, 2011), XXI-XXII. 
miento de las aguas, por obras o hechos recientes, podrá ocurrir ante el Juez competente a fin de que se le ampare en su derecho.

Esta disposición se refiere a la propiedad sobre el derecho de aguas no inscrito, la que es permanente y sujeta no sólo a esta protección procesal, sino también a la intangibilidad que garantiza el artículo 19 n. ${ }^{\circ}$ 24 inciso final de la Constitución.

ii) La derogación contenida en el artículo $308 \mathrm{CA}$ no cubre, ni podría cubrir, el DL 2.603 de 1979. Dice tal artículo: "Deróganse todas las disposiciones legales y reglamentarias que tratan sobre las materias contenidas en el presente código, y en especial las siguientes...", y mencionando a continuación varias leyes.

Es ésta una cláusula de derogación orgánica bastante ambigua, pero, en lo que respecta al DL 2.603, esta derogación no le alcanza, por cuanto, por una parte, no aparece mencionado en dicho precepto y, por otra, y lo que es sustantivo, el señalado DL 2.603 reglamenta otras materias, diversas de aquéllas reguladas en el CA. En estas materias, el DL 2.603 es especial frente al CA; de lo que es prueba el que este Código no establezca presunciones de dominio de derechos de aguas.

Incluso más, no tenía fuerza suficiente para derogarlo, pues el propio CA fue dictado en virtud de una facultad conferida por el artículo 2 DL 2.603 de 1979, prorrogada por el DL 3.337 de 1980 y renovada por el DL 3.549 de 1981. El CA es un DFL (cuya constitucionalidad, incluso, por referirse a garantías constitucionales, merecía dudas; no obstante, ha sido modificado por leyes posteriores, las que, entonces, lo ratifican tácitamente). En consecuencia, mal puede un cuerpo normativo derogar la norma en cuya virtud fue dictado.

\subsubsection{Un régimen jurídico permanente en una norma "transitoria"}

No se deben confundir las leyes temporales con las normas transitorias. Como señalo antes, la regla procesal que regula el procedimiento de regularización de los derechos consuetudinarios de modo permanente (pues no establece fecha alguna de vigencia) es el artículo 2 transitorio del CA.

Se podría llegar a confundir las particularidades de una ley de carácter o eficacia temporal (esto es, aquella que fija ella misma, de un modo explícito, una duración limitada de vigencia para su mandato) 
con la ubicación de una ley ordinaria (esto es, aquella que establece una relación permanente entre su presupuesto de hecho y sus efectos jurídicos). Esta clasificación de las leyes entre ordinarias y temporales es usual en teoría de la legislación, ${ }^{20}$ y en nada altera el carácter ordinario de una norma por el solo hecho de que el legislador la ha llamado "transitoria" o la ha situado en un apartado en que sitúa las que llama "normas transitorias". El desorden legislativo en esta materia es usual, y ocurre en Chile y en el derecho comparado (en donde ha habido intentos de sistematización o de ordenamiento dogmático). ${ }^{21}$

Por lo tanto, en el caso del artículo 2 transitorio del CA ha de estarse a los términos explícitos de esa norma, la que no indica fijación temporal alguna para su propia vigencia; de ahí que esta norma podrá ser invocada mientras ella esté vigente y no haya sido derogada, dado su carácter ordinario y permanente. Además, no sólo no hay dudas a partir de su propio texto de que no es una norma temporal, sino que, en caso de que se quisiese fijar una temporalidad para la misma, no existiría criterio alguno para hacerlo.

\subsection{Corolario: Los usos consuetudinarios de aguas son unos derechos plenamente válidos, sin plazo legal para ser regularizados}

A partir del desarrollo anterior, no hay dudas entonces de la plena validez de los usos y derechos consuetudinarios de aguas, de la plena vigencia de las normas sustantiva y procesal que los rigen y de que no existe plazo alguno para que los titulares de esos derechos puedan realizar esa regularización.

${ }^{20}$ Ver, para Chile, un desarrollo sobre las disposiciones transitorias, y las diferentes clases de ellas, según su contenido y con ejemplos, en Alejandro Vergara. "Formación de la ley y técnica legislativa", en Diagnóstico histórico jurídico del Poder Legislativo en Chile: 1960-1990 (Valparaíso: Centro de Estudios y Asistencia Legislativa, Universidad de Valparaíso, 1993), 189-192; y Alan Bronfman, "La división de las leyes", en La técnica legislativa ante la elaboración de la ley (Valparaíso: Centro de Estudios y Asistencia Legislativa, Universidad de Valparaíso, 1998), 186-190. Para España: Carles Viver i Pi-Sunyer, "La parte final de las leyes", en La forma de las leyes. 10 estudios de técnica legislativa, de Gretel — Grupo de Estudios de Técnica Legislativa - (Barcelona: Bosch, 1986), 135-172, y para Francia: Jacques Héron, Principes du droit transitoire (París: Dalloz, 1996).

21 Ver el extenso y detallado trabajo de Gweltaz Éveillard, Les dispositions transitoires en droit public français (París: Dalloz, 2007). 
Todo esto ha formado, por décadas, la práctica administrativa de la Dirección General de Aguas de tramitar estas solicitudes de regularización por parte de los titulares, ${ }^{22} \mathrm{y}$ aun promoviendo a través de fondos públicos tales regularizaciones, como es el caso de la práctica administrativa usual de la Comisión Nacional de Riego.

Sin embargo, ésta ha venido a ser amagada por la jurisprudencia de la Corte Suprema, a partir de diciembre de 2014, según explico más adelante.

\section{EL VALOR DE LA POSESIÓN Y USO ANCESTRAL DEL AGUA EN LA JURISPRUDENCIA TRADICIONAL DE LA CORTE SUPREMA (HASTA JULIO DE 2014)}

La línea jurisprudencial tradicional de la Corte Suprema, y uniforme hasta julio de 2014, había venido aceptando la suma de posesiones en las regularizaciones de derechos consuetudinarios de aguas; criterio que había sido mantenido de modo consistente y fundado, por largos años. De hecho, se había profundizado desde 2004, en varios casos relevantes, en especial relativos a derechos de aguas de indígenas y agricultores. Una revisión detenida de la jurisprudencia de la década de 2004 hasta julio de 2014 muestra que la Corte no sólo aplicó criterios uniformes y coherentes con la legislación y los hechos, en los cuales cabía reconocer y proteger tales usos efectivos y costumbristas, sino que también aceptó para su regularización la suma de posesiones, atendida la naturaleza de su origen y el uso de las aguas. Véase en el Anexo 9.1 la enumeración de todos los casos, los que podemos distinguir entre casos de indígenas y agricultores.

${ }^{22}$ Ver los dos siguientes actos administrativos de orden interno, bien explícitos al respecto, y en base a los cuales se tramitan tales solicitudes al interior del órgano administrativo competente: Dirección General de Aguas, Ministerio de Obras Públicas, Instructivo artículo 2 transitorio del Código de Aguas. Ord. n. ${ }^{\circ} 725$ de 5 noviembre 1999, que aprueba Minuta n. ${ }^{\circ} 165$, de 28 de octubre de 1999, y Dirección General de Aguas, Ministerio de Obras Públicas, Manual de normas y procedimientos para la administración de recursos hídricos, 2008. S. I. T. n. ${ }^{\circ}$ 156. Ambos documentos conforman un hilo de continuidad de décadas, y no sólo reconocen explícitamente la suma de posesiones, sino que además dan instrucciones específicas para la tramitación de tales solicitudes. 


\subsection{El caso de los usos y derechos de indígenas}

Respecto de los usos ancestrales por indígenas, en "Comunidad Atacameña Toconce con Essan" (2004) y en el famosísimo caso "Agua Mineral Chusmiza con Comunidad Indígena Aymara de Chusmiza Usmagama" (2009) la Corte Suprema declaró el entero reconocimiento como derechos plenos de esos usos ancestrales, con una unión evidente de posesiones históricas para la prueba del uso del agua. En ambos casos, la Corte consideró y le dio valor a la prueba de "usos ancestrales" y efectivos por generaciones de indígenas para reconocerlos como derechos; son los propios indígenas quienes solicitaron la regularización (en "Toconce con Essan") o se opusieron a una solicitud que les afectaba (en "Agua Mineral Chusmiza"), invocando sus usos efectivos de las aguas desde tiempos inmemoriales.

Los usos ancestrales fueron reconocidos como derechos en el DL 2.603 de 1997 y la Constitución Política de 1980, y se constituyen, naturalmente, por una suma de posesiones de las diversas generaciones de indígenas; es decir, abuelos, padres, nietos, y así sucesivamente, han usado el agua, en un lugar específico, originándose el actual derecho real.

Habría sido un despropósito negarle la regularización de un derecho consuetudinario o ancestral de aguas al solicitante, por el hecho de ser parte de una nueva generación de indígenas y por no haber realizado él mismo un "uso personal" del agua, como lo hacían sus ancestros. Nunca en esta antigua línea jurisprudencial se realizó la exigencia del uso "personal" del agua por el solicitante, tanto en 1981 como al solicitar la regularización, pues ello habría significado que al fallecimiento de una generación de indígenas ya no podrían sus sucesores regularizar sus derechos ancestrales. El mismo criterio debiese aplicarse para todo tipo de usuarios, sean indígenas o no, como reviso a continuación.

\subsection{El caso de los usos agrícolas}

Diversos casos se refieren a usos de aguas con fines agrícolas como "Espinoza con Endesa" (2005); "Agrícola Victoria con Endesa" (2007); "Agrícola Forestal Los Olivos" (2009); "Garrido Aedo con DOH" (2011); "Sociedad Agrícola Pangue" (2011); "Agrícola Santa Lucía Ranch" (2012); "Sociedad Agrícola el Piedrero" (2013), y "Sociedad 
Agrícola el Porvenir" (2016). Su situación es la misma, pues tratándose los derechos de aguas de derechos reales la Corte Suprema acepta la suma de posesiones, entre sucesivos sucesores de títulos de derechos antiguos.

En "AES Gener con DGA" (2011) — que cita como precedentes a "Comunidad Atacameña Toconce" (2004) y "Garrido con DOH" (2011) - , la Corte Suprema enfatiza en su considerando 16 que "los usos consuetudinarios son genuinos derechos que hay que respetar como tales, situación reconocida incluso a nivel constitucional" y, en coherencia con ello, procede a validar la suma de posesiones de tales derechos.

Lo sigue en especial "Sociedad Agrícola El Piedrero con Endesa" (2013), sentencia redactada con gran detalle, que se refiere a los "usos desde tiempos inmemoriales", suficientemente probados en la causa; cita como precedentes buena parte de las sentencias anteriores y, en fin, señala respecto de la suma de posesiones (considerando 13), que, "al tenor de la doctrina señalada, aparece lícito y posible que los usuarios de derechos de aprovechamiento no inscritos agreguen a la propia la posesión de sus antecesores".

Son sentencias matrices de esta línea jurisprudencial las de "Toconce" (2004) y "Espinoza" (2005), ambas redactadas por el ministro Urbano Marín, cuya huella argumental, traspasada de sentencia en sentencia, subsiste hasta en las más recientes; por ejemplo, en "Sociedad Agrícola el Porvenir con DGA" (2016).

Esta sólida línea jurisprudencial se desarrolla en coherencia con los hechos (el factum de la materia), en línea con las fuentes - la costumbre, aceptada por la ley vigente- - y también en concordancia con la doctrina de los autores, que ella cita profusamente. Esta jurisprudencia tradicional se caracteriza por:

i) El valor que le asigna a los usos y derechos consuetudinarios de aguas; esto es, aquéllos originados en el uso ancestral del agua.

ii) La comprensión, respeto y protección de los derechos de aguas consuetudinarios, sobre las consecuencias del uso ancestral y efectivo del agua por largos años, como fuente de posesión y reconocimiento jurídico de derechos de aguas.

iii) La aceptación de la suma de posesiones de esos derechos reales entre sus diversos titulares consecutivos para permitir así la regularización o formalización de tales títulos de aguas por sus actuales titulares. 
iv) Constituir una racional interpretación de las leyes atinentes y por conectarse de manera coherente con el factum de todo uso costumbrista del agua.

\section{GIRO JURISPRUDENCIAL DE FINES DE 2014 Y CUATRO AÑOS DE VACILACIONES O ZIGZAGUEO}

En efecto, la Corte Suprema (o, de una manera más precisa, su Tercera Sala), desde diciembre de 2014 y hasta agosto de 2018 (última fecha de este análisis), cambió radical, inesperada y negativamente el criterio que ella misma (con la intervención de otras salas y otros ministros) había construido con anterioridad, al menos desde la vigencia del Código de Aguas de 1981, en materia de regularización de derechos consuetudinarios de aguas. Cabe observar de cerca la génesis del cambio y antecedentes coetáneos. ${ }^{23}$

\subsection{El criterio tradicional y el cambio}

La jurisprudencia de la Corte Suprema venía declarando, por muchos años y hasta fines de 2014 (véase Anexo 9.1), de manera sostenida, en sentencias unánimes y sin votos disidentes, sin zigzagueo alguno, que era posible que los titulares de derechos consuetudinarios de aguas pudiesen, al regularizarlos, sumar a la propia la posesión de los anteriores titulares de los mismos, utilizando una institución jurídica perteneciente a los derechos reales, como es la suma o agregación de

23 En 2016, 2017 y 2018 realicé sobre este cambio jurisprudencial cuatro comentarios que ahora refundo, actualizo y sistematizo. Esta reunión me permite observar la conducta judicial respecto de este tema en todo el período de casi cuatro años, lo que muestro en diversos gráficos más adelante. Véase Alejandro Vergara, "Regularización de derechos consuetudinarios de aguas y suma de posesiones en todo derecho real", El Mercurio Legal, 3 febrero 2016; "Regularización de derechos consuetudinarios de aguas: el valor de la posesión y uso ancestral del agua (parte II)", El Mercurio Legal, 22 febrero 2017; "Regularización de derechos consuetudinarios de aguas: génesis y efectos de una nueva línea jurisprudencial (parte III)", El Mercurio Legal, 13 abril 2017, y, "Regularización de derechos consuetudinarios de aguas: dispersión jurisprudencial en 2017 (parte IV)", El Mercurio Legal, 10 enero 2018. Los tres primeros trabajos fueron también reproducidos en Alejandro Vergara, "Derecho de aguas: Identidad y transformaciones", 258-278; la nota final de página 278 fue, como se ve, una vana esperanza. 
Gráfico 1. RESOLUCIONES DE LA CORTE SUPREMA DESDE PRINCIPIOS DE 2004 HASTA JULIO 2014, EN DERECHOS CONSUETUDINARIOS DE AGUA

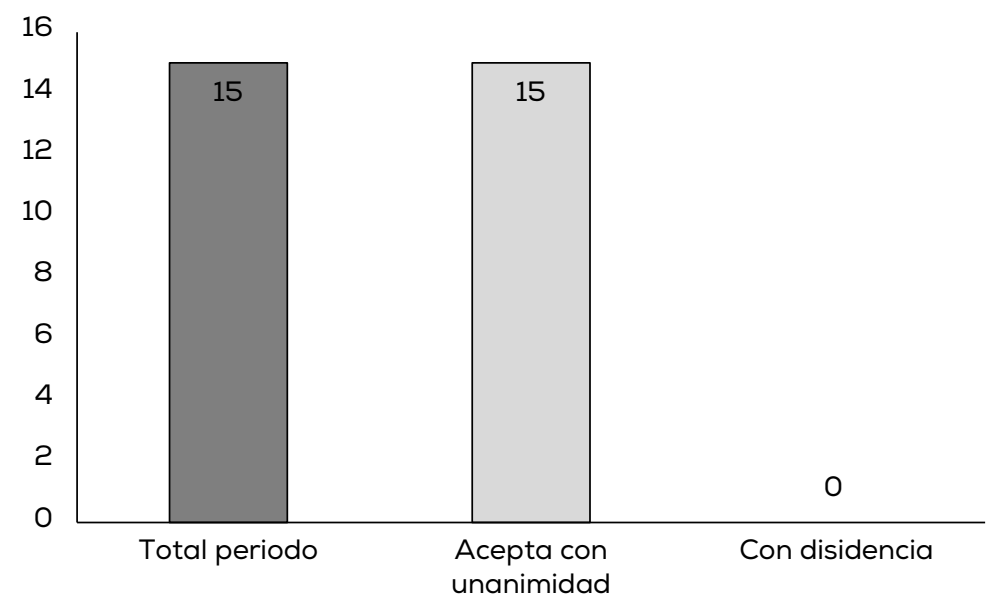

posesión del título. ${ }^{24}$ Ello había configurado una sólida base jurídica legal, jurisprudencial y doctrinaria en cuanto a los usos consuetudinarios de aguas, con conciencia por esos jueces de seguir los precedentes (así lo consignan las respectivas sentencias); aplicando a casos de agricultores, indígenas y usuarios diversos el razonable criterio legal de agregar las posesiones anteriores para el cómputo de plazo requerido para regularizar este derecho real. La carga de la prueba pesaba sobre el regularizador, quien debía comprobar no sólo el uso efectivo y actual del agua, sino también el uso requerido de cinco años a través de la suma de posesiones anteriores, si es necesario (sin perjuicio de la dificultad que hoy ello representa, por haber transcurrido más de tres décadas desde la entrada en vigor del Código de Aguas).

Pero, en diciembre de 2014 la Corte Suprema dictó una sentencia contradictoria con esa línea en el caso "Inversiones de la Cerda con

${ }^{24}$ Ofrezco en el Anexo 9.1 una relación exhaustiva de los casos anteriores. Si se observa, en toda la década anterior (desde 2004 a 2014) la jurisprudencia fue uniforme en cuanto a aceptar la accesión de posesiones. No existen registros completos de la jurisprudencia anterior a 2004, pero pueden verse algunas sentencias publicadas en la Revista de Derecho de Aguas (que circuló los años 1990 a 1998) o los escasos casos de la materia que publicó la Revista de Derecho y Jurisprudencia. En ninguno de los casos ahí publicados se había generado la discusión jurídica que se planteó en la jurisprudencia a partir de diciembre de 2014. 
Endesa" (2014). La que en un principio pareció una rara y solitaria sentencia pasó a ser el hito a partir del cual se alteró la uniforme casuística anterior. Pareció un simple desliz de la Corte Suprema, pero meses después, a fines de 2015, se comenzó a notar un radical giro jurisprudencial. En verdad fue un descalabro, pues hasta agosto de 2018 se sumaron 17 casos más (totalizando así 18), cuya última muestra es "Soto Valdivia" (2018). Todas ellas contradijeron la vigorosa línea anterior de la Corte Suprema en esta materia (véase Anexo 9.2).

Una crónica sucinta del período que va desde diciembre de 2014 a agosto de 2018 es la siguiente:

i) Se ha mantenido de manera paralela en la Tercera Sala de la Corte Suprema la línea jurisprudencial más antigua, ofreciendo así aquella sala un espectáculo lamentable para la suerte de los justiciables: el resultado en uno u otro sentido ha dependido de la integración que la sala tenga el día de la vista y acuerdo de la causa, por lo que la sentencia que se emita puede ser de una u otra línea jurisprudencial.

ii) En las causas de la nueva línea se han consignado votos disidentes de los ministros que sostienen la línea paralela (en caso de integrar la sala).

iii) La conducta culmen es la de ministros que se contradicen en causas idénticas, una y otra vez, en un zigzagueo respecto de sus propios votos y redacciones anteriores, de lo que resulta que no es posible saber cuál es la posición que sustenta o sustentará ese mismo ministro en una próxima causa sobre la materia.

Entonces, la situación actual de la jurisprudencia de la Corte Suprema es en extremo vacilante y dividida, existiendo dos líneas jurisprudenciales paralelas, pues aún se ha mantenido la línea anterior en cinco casos (véase Anexo 9.3), aun cuando la más persistente desde 2014 por mayoría de votos en la Tercera Sala de la Corte Suprema (donde están radicados los temas de aguas), es la nueva doctrina.

\subsection{Génesis y crónica detallada de la nueva línea jurisprudencial de la Corte Suprema en regularización de derechos de aguas}

Las 18 sentencias de la nueva línea jurisprudencial que niegan la posibilidad de que los nuevos adquirentes de antiguos derechos de aguas — originados en usos consuetudinarios - puedan realizar la re- 
gularización de sus títulos producen graves efectos prácticos sobre el principio de la certeza jurídica.

Un elemento común en casi todas las sentencias que dieron origen a esta doctrina en 2014 es que la redacción del fallo ha provenido de abogados integrantes que fueron circulando en la Tercera Sala entre 2014 y 2016, y a los cuales adhirieron algunos ministros. Las sentencias del antiguo criterio, en cambio, fueron todas redactadas por ministros titulares. Curiosamente, uno de esos abogados integrantes (el actual ministro Prado, que fue abogado integrante hasta abril de 2017, momento en que pasó a ser ministro titular ocupando el cupo dejado por el ex ministro Pierry) fue el redactor de la sentencia que dio origen a esta nueva línea jurisprudencial, "Inversiones de la Cerda" (2014). Sin embargo, más tarde cambiaría de opinión una y otra vez, zigzagueando tres veces más. En efecto, en "Vera Urra" (2017) da un primer giro sobre su voto anterior redactando un fundado fallo para la línea tradicional; luego cambia nuevamente de opinión en "Zúñiga Lara” (2017), pero disiente en "Soto Valdivia" (2018) retornando a la línea tradicional a través de un fundado voto en que de modo sorprendente contradice fundamentos que él mismo había redactado en sentencias anteriores. En fin, en "Toconce con SQM" (2018) sus criterios se dispersan aún más, pues en un críptico voto disidente confunde el uso particular con el uso comunitario o ancestral de las aguas por una comunidad indígena. Cabe señalar que en todos estos casos la base fáctica es idéntica.

\subsubsection{Recuento del giro jurisprudencial}

Un recuento de lo ocurrido desde diciembre de 2014 es el siguiente:

i) Con "Inversiones de la Cerda Olivo Limitada con Empresa Nacional de Electricidad S.A.” (2014), la Corte Suprema por vez primera rompe el limpio precedente anterior. Su redactor: un abogado integrante (Prado).

ii) Un año después, en noviembre de 2015, en "Inversiones y Asesorías FTM Limitada con Empresa Nacional de Electricidad S.A." (2015) se ofrece un nuevo fallo, que extiende el descalabro ya iniciado; cita, además, de manera descuidada las sentencias de los roles n. ${ }^{\circ}$ 108404 y n. ${ }^{\circ}$ 5342-06, haciéndolas parecer falsamente como precedentes, aunque en realidad se las contradice. Su redactor: otro ocasional abogado integrante. 
iii) Lo sigue "Vidal González, Francisco con Empresa Nacional de Electricidad S.A." (2015), que cita como precedente el caso "Inversiones de la Cerda Olivo con Endesa" (2014). Redactor: otro abogado integrante, distinto a los anteriores, que simplemente copia texto de la sentencia anterior.

iv) Los restantes casos continúan la nueva línea jurisprudencial: "Arturo Amenábar Vives con Dirección General de Aguas" (2016); "Rojas Gil con Dirección General de Aguas" (2016) y "Agrícola Alianza S.A. con Empresa Nacional de Electricidad S.A." (2016). En estos dos últimos casos se cita las sentencias de los roles n. ${ }^{\circ} 1084-2004$ y n. ${ }^{\circ}$ $16.578-2014$ y se las hace parecer como precedentes, pero en realidad se las contradice completamente. Redactores: otros abogados integrantes distintos a todos los anteriores. En los casos posteriores, desde "Rivera con Endesa" (2016) y hasta "Syngenta con Aguas del Altiplano" (2017), sus redactores son nuevos y distintos abogados integrantes, y en alguna ocasión ministros de la sala, pero todos siguen el texto de "Inversiones con Endesa" (2015).

\subsubsection{Votos disidentes que mantienen la línea tradicional}

No obstante, en gran parte de los casos de 2016 y 2017 de la nueva línea jurisprudencial existen votos disidentes; votos que, si bien escuetos en sus desarrollos, siguen la tradición jurisprudencial anterior.

En efecto, en los casos "Sociedad Agrícola La Italiana con DGA" (2016), "Pérez con DGA" (2016), "Amenábar con DGA" (2016) y "Syngenta con Aguas del Altiplano" (2017) consignan sus votos disidentes los ministros Egnem y Muñoz (Sergio) cada vez que integran la sala. También se ha unido a los disidentes tradicionales el ministro Prado, aunque con algún zigzagueo adicional, en especial en "Soto Valdivia" (2018).

Estos ministros señalan que "de la lectura del artículo 2 transitorio del Código de Aguas no es posible desprender que contemple como presupuesto indispensable para acceder a la regularización allí dispuesta la circunstancia que el regularizador haya hecho uso personalmente del derecho de aprovechamiento de aguas a la fecha de entrada en vigencia del Código de Aguas". Citan, además, la importante presunción del artículo 7 DL 2.603, de 1979, y la existente doctrina de los autores de Derecho de Aguas. 
3.2.3. Una corte dividida: consolidación de dos líneas paralelas en 2017 y 2018

Cabe consignar que entre diciembre de 2014 y mayo de 2018 la Corte Suprema ha emitido, de forma paralela y contradictoria a esta nueva línea, cinco fallos que siguen sosteniendo la antigua doctrina. ${ }^{25}$ Son los casos "Sociedad Agrícola El Porvenir" (2016); "Díaz con Mulluri" (2017); "Vera Urra" (2017); "Matta con Aguas del Altiplano" (2017) y "Toconce con SQM" (2018). De esta manera el antiguo criterio aún no es completamente sustituido y en la práctica depende de la integración de la Tercera Sala de la Corte Suprema. Además, por ejemplo, en "Development con DGA" (2014), que es la summa de los criterios uniformes anteriores, la Corte Suprema no sólo acogió el criterio de observar y respetar el uso efectivo anterior a 1981, sino que también validó la suma de posesiones de los antecesores y sucesores del derecho real de aguas.

Si observamos el panorama completo de los últimos dos años (todo 2017 y hasta agosto de 2018), en que la Corte Suprema se enfrentó en nueve ocasiones a causas idénticas de regularización de derechos de aguas, el resultado es el siguiente: en cuatro casos falló a favor de la posición tradicional, y en cinco casos falló a favor de la nueva tendencia, contraria a la anterior. Esto constituye, entonces, una clara dispersión jurisprudencial.

\subsection{Una muestra: los casos de 2017 en que se acepta la suma de posesión de derechos de aguas}

i) En "Díaz con Comunidad Indígena de Mulluri” (2017), relativa a una comunidad indígena, generó un vuelco en el criterio negativo a las regularizaciones que venía sosteniendo la Corte y acepta la regularización de estos derechos consuetudinarios por parte de la comunidad indígena Mulluri sobre aguas que se "vienen usando hace más de 50 años y por generaciones anteriores". Según la Corte (considerando décimo), se cumple con todas las exigencias estipuladas por el artículo 2 transitorio del $\mathrm{CA}$, sin exigirse a las diversas generaciones de indígenas en ningún momento el tan repetido uso personal a que se refieren sentencias de la

25 Ver Anexo 9.3. 
línea jurisprudencial paralela. Lo curioso aquí es que el caso se decidió por la unanimidad de la Tercera Sala, con votos incluidos de los ministros Sandoval, Aránguiz, Valderrama y abogado integrante Quintanilla, todos, férreos opositores a la regularización según sus votaciones anteriores y posteriores. Sólo el ministro Muñoz, participante de la misma votación, había votado a favor de las regularizaciones.

ii) En "Vera con DGA" (2017), la Corte Suprema nuevamente accede a una solicitud de regularización en un caso en el que el solicitante no ha sido quien ha efectuado el uso de las aguas de manera personal, señalando en el considerando duodécimo que, "entre los requisitos de fondo exigidos por el precepto transcrito, el aspecto sustancial que conforma todo el sistema regulatorio se refiere a la utilización de las aguas por un poseedor no inscrito", no distinguiendo si aquel poseedor debe ser el mismo solicitante de regularización. Aún más, en el considerando siguiente señala expresamente, y luego de citar doctrina, que "aparece lícito y posible que los usuarios de derechos de aprovechamiento no inscritos agreguen a la propia la posesión de sus antecesores, considerando especialmente que el objeto del inciso segundo del artículo 2 transitorio es el de regularizar derechos de aprovechamiento no inscritos".

El razonamiento de esta sentencia podría indicarnos un regreso a la doctrina tradicional que había sostenido la Corte Suprema desde vieja data, pues fue redactada por el actual ministro Prado, que así se desdecía de los anteriores votos en que, como abogado integrante, había firmado para la línea jurisprudencial contraria. Sin embargo, la sentencia fue pronunciada con el voto disidente de dos ministros sostenedores de la tesis contraria, Sandoval y Aránguiz, quienes en la redacción del voto insisten en la necesidad de un uso personal de las aguas.

iii) En "Matta con Aguas del Altiplano" (2017), la Corte se pronunció a favor de la regularización. Destaca en este fallo el considerando octavo, el cual se refiere en específico al estatuto de los derechos consuetudinarios a la luz del DL 2.603 y el art. 19 n. ${ }^{\circ} 24$ de la Constitución, por cuanto la propiedad alcanza a este tipo de derechos, siendo el 2 transitorio del CA un mecanismo legal para regularizar tales usos. Continúa el considerando noveno señalando que, de acuerdo al artículo 7 del DL 2.603, se infiere que el propósito de esta norma es "que los usos de agua que cumplan determinados requisitos, constituyan dere- 
chos" y que, en virtud del 2 transitorio del CA, la intención del legislador ha sido "que tales usos se validen a través de su inscripción en el Registro Conservatorio Respectivo". Haciendo énfasis en que estos derechos no están siendo constituidos, pues ya existen y su propiedad no se discute.

Luego, en el considerando undécimo, se reafirma que en relación con la exigida utilización de las aguas lo único que se requiere es que a la fecha de entrada en vigencia el CA el derecho de aprovechamiento haya estado amparado por la presunción del artículo 7 del DL 2.603, "no siendo necesario que el regularizador haya estado personalmente haciendo uso de ese derecho a la fecha de entrada en vigencia el actual Código de Aguas", resultando procedente que "el peticionario continuador legal en el aprovechamiento del derecho a regularizar, pueda adicionar a su tiempo de uso ininterrumpido el de sus antecesores".

Finalmente, esta sentencia remarca en el considerando decimosegundo aquel precepto olvidado por la línea jurisprudencial de la Corte Suprema que rechaza la regularización: me refiero al inciso segundo del artículo 7 de DL 2.603, que establece una presunción aplicable a quien actualmente se encuentre utilizando las aguas o "a la época en que se invoca la presunción, indefectiblemente debe concluirse que no es necesario que el interesado haya estado personalmente haciendo uso del derecho a la entrada en vigencia del Código de Aguas".

Esta última sentencia llama aún más la atención, por cuanto ha sido pronunciada por la unanimidad de la sala, aun cuando dos de sus integrantes, en sus votaciones pasadas, fueron partidarios de la línea que rechaza las regularizaciones bajo el argumento de la transitoriedad y del uso personal.

iv) En "Toconce con SQM" (2018), la Corte se pronuncia a favor de la regularización, pero su tendencia pro indígena esta vez la recubre con un desarrollo fundado en la Ley Indígena, en su conexión con la legislación de aguas.

\subsection{Otra muestra: los casos de 2017 y 2018 en que no se acepta la suma de posesión de derechos de aguas}

La tendencia al rechazo de las regularizaciones también se mantuvo durante 2017 y 2018 : 
i) "Syngenta con Aguas del Altiplano" (2017) es un falso caso de regularización, podríamos decir, pues no había necesidad de invocar los argumentos de fondo dado que, como bien lo dice en su prevención el ministro Muñoz, cabía rechazar la regularización por un descuido del solicitante: la falta de prueba en el uso de las aguas en las fechas correspondientes.

ii) "Chambe con Aguas del Altiplano" (2017) sigue el criterio de la nueva línea.

iii) En "Medina Maturana con DGA" (2017), se rechaza la solicitud de regularización basándose en la argumentación usual, señalando en el considerando octavo que "la transitoriedad de la disposición impide considerar su aplicación a usos originados con posterioridad a aquella data, pues tal interpretación conspira con su naturaleza, pues la transforma en un precepto de carácter permanente, convirtiendo así una situación excepcional en una forma general de regularización, cuestión que es improcedente". Luego, el considerando siguiente se refiere al requisito creado por la Corte Suprema respecto al uso personal de las aguas: "Que realice personalmente el solicitante de regularización". ${ }^{26}$

iv) En "Zúñiga con DGA" (2017), se acoge un recurso contra una sentencia que había accedido a la solicitud regularizadora principalmente gracias al argumento sostenido en el considerando séptimo, según el cual la regularización requiere "una utilización ininterrumpida por cinco años al menos del recurso hídrico, desde antes de la vigencia del actual estatuto legal sobre la materia. Esta exigencia sólo puede ser entendida como comprensiva del uso que de las mismas efectuaba personalmente el solicitante de regularización a la fecha de entrada en vigencia del Código de Aguas y en los cinco años anteriores, esto es, con exclusión de cualquier uso anterior efectuado por terceros distintos".

v) En "Soto Valdivia" (2018), también se rechaza la solicitud de regularización, repitiendo los mismos argumentos. Se insiste en el argumento-interpretación del carácter "transitorio" de la norma contenida en el art. 2T del CA, para finalmente sostener que se infringe la norma del 2 transitorio del CA cuando se agrega la posesión regulada por el artículo 717 del Código Civil, toda vez que éste sería un régimen excepcional

${ }^{26}$ Esta sentencia fue pronunciada por la unanimidad de la sala (lo que ha ocurrido en contadas ocasiones), la cual estaba integrada también por el ministro Sergio Muñoz, quien se había mostrado partidario de aceptar la regularización. 
que no recibe aplicación en esta materia. La razón de ello está dada por el tenor literal de la norma que se sostiene, en cuanto ella se referiría a los derechos de aprovechamiento que "estén siendo utilizados a la fecha de entrada del código", los cuales pueden ser regularizados en el evento de que los respectivos "usuarios hayan cumplido cinco años de uso ininterrumpido". Sin contener la norma "ningún elemento que permita entender que el mecanismo por ella reglamentado pueda beneficiar a personas distintas de quien hacía uso de las aguas al 29 de octubre de 1981 y, por el contrario, de su propio texto aparece que la exigencia legal en análisis abarca, exclusivamente, la utilización personal que de ellas hacía el solicitante de regularización a esa fecha". ${ }^{27}$

\section{ANÁLISIS Y CRÍTICA DEL CAMBIO JURISPRUDENCIAL}

\subsection{Una explicación del cambio: radicación de los temas de aguas en la Tercera Sala desde finales de 2014}

Puede explicarse en parte el cambio jurisprudencial por la radicación de los temas de aguas en la Tercera Sala de la Corte Suprema desde fines de 2014, según el auto acordado que fija la distribución de materias entre las distintas salas de la Corte. ${ }^{28}$ El cambio jurisprudencial coincide entonces con la entrada en escena de los ministros integrantes de esa sala — Sandoval, Pierry y Aránguiz—, todos quienes aparecen en causas relativas a la materia a partir de diciembre de $2014,{ }^{29}$ y quienes, desde el primer caso que conocieron, se presentan como opositores a la línea jurisprudencial anterior.

A fines de 2014, entonces, dejan de conocer estas causas algunos de los ministros que con mayor frecuencia tuvieron intervención a favor de la suma de posesión en la regularización en el periodo anterior (hasta julio de 2014, fecha de la última sentencia anterior). La excepción es el

${ }^{27}$ Cabe destacar que en esta sentencia la ministra Egnem manifiesta su consistente y sistemático voto en contra.

${ }^{28}$ La radicación de las causas de aguas en las distintas salas de la Corte Suprema, en los últimos años, es la siguiente: $1^{\circ}$ ) por auto acordado de 24 de julio de 2009 se radicaron en la Segunda Sala; $2^{\circ}$ ) luego, por auto acordado contenido en el acta 68-2012 del 4 de junio de 2012, se radicaron en la Primera Sala, y $3^{\circ}$ ) por auto acordado de 26 de diciembre de 2014, contenido en el acta 233-2014, se radican en la Tercera Sala, la que desde entonces se ha mantenido.

${ }^{29}$ Véase Anexo, en que ofrezco la relación de causas, sentencias y ministros. 
ministro Rodríguez, quien siguió conociendo de estos temas, pero paradójicamente comenzó en el nuevo periodo (desde diciembre de 2014 en adelante) a emitir votos en contra de su antiguo parecer. De una manera similar actuó el ministro Silva, quien al parecer comenzó a dudar de su punto de vista al presentar votos contradictorios: uno a favor y otro en contra, lo cual puede verse más adelante en los gráficos respectivos.

Destaca en el periodo que parte en diciembre de 2014, entonces, la presencia de los ministros Sandoval, Pierry y Aránguiz, miembros permanentes de la Tercera Sala. Estos ministros parecieran votar en bloque, siendo seguidos en su razonamiento por otros ministros ocasionales o por abogados integrantes (y muchas veces redactores), a menos que aparezca en el panorama, como analizo más adelante, la ministra Egnem, quien es la más férrea disidente en la materia, el ministro $\mathrm{Mu}-$ ñoz u ocasionalmente el ministro Prado, en medio de uno de sus zigzagueos.

Entonces son unos nuevos jueces de la Corte Suprema los que comienzan a conocer las causas de aguas a fines de 2014 y desde ahí todo cambiará.

\subsection{Los efectos del cambio jurisprudencial}

Este nuevo criterio, como es natural, ha venido sembrando incerteza en los titulares de esos derechos consuetudinarios de aguas, usualmente agricultores e indígenas (aunque estos últimos, como muestro más adelante, suelen tener un trato especial en la jurisprudencia). Esta incerteza no ha provenido esta vez de la sequía o de alguna acción de facto de un usurpador de aguas; ni de un cambio regulatorio negativo, obra del legislador; ni de la actuación arbitraria de algún órgano de la administración, sino que, paradójicamente, tal incerteza ha provenido de la propia Corte Suprema, la que es considerada un bastión de la juridicidad, en donde los particulares buscan razonabilidad y seguridad jurídica, justicia en otras palabras. Pues, como muestro más adelante, todas las demás fuentes del derecho en esta materia han sido desconocidas en estas sentencias, una por una: la ley vigente, la costumbre, la doctrina de los autores y todo el caudal de jurisprudencia anterior a 2014 de ese mismo alto tribunal.

Los fundamentos que ofrecen las sentencias de este cambio jurisprudencial son sorprendentes, dado que, conforme argumento más 
adelante, la nueva línea jurisprudencial carece de razonabilidad jurídica y pareciera sustentarse más bien en intuiciones y apreciaciones discutibles e incluso superficiales de sus sostenedores. A lo anterior se agrega otro aspecto negativo. Este cambio se ha producido en medio de una conducta doblemente zigzagueante en causas idénticas; tanto por parte de una de las salas de la Corte Suprema, la que como órgano jurisdiccional está sujeta a estándares democráticos (entre los cuales, la ausencia de cambios intempestivos es muy relevante: la política de precedentes sostenidos en el tiempo), como por parte de algunos de sus ministros, que han cambiado de posición una y otra vez. En este trabajo muestro la evidencia de tales vacilaciones.

\subsection{El argumento contrafáctico de las sentencias y la incerteza que producen}

En esta retahíla de sentencias de la nueva línea jurisprudencial (todas las cuales tienen una redacción casi idéntica) se usa como argumento extra legem el hecho de haber transcurrido más de treinta años desde 1981 sin que estas situaciones se hayan regularizado, lo que se tilda de "irregular" (como si lo consuetudinario fuese ilegítimo). Ésta es una de las razones para privar de tal regularización a quien precisamente se lo pide. Los argumentos se han presentado de la siguiente manera:

i) Recalca la Corte el hecho de que el tema está regulado en una disposición "sólo" transitoria (art. 2 transitorio del CA), como si un mandato legal que está contenido en una disposición llamada "transitoria" fuese de menor calidad regulatoria. Se esgrime como obstáculo el supuesto carácter provisorio de la norma, sin parar mientes dichos sentenciadores en que las disposiciones transitorias, en técnica legislativa, no dicen necesaria relación con su corta o larga vigencia, o duración, sino con su aptitud para regular situaciones "de tránsito" entre dos regímenes, uno antiguo y uno nuevo, cuyo es el caso. Este tema lo analizo en la sección 1.6.2.

Pues, aunque parezca extraño, este artículo 2 transitorio del CA es una disposición de "tránsito" que se ha aplicado de manera muy prolongada, sin ilegitimidad jurídica alguna, sin perjuicio de no existir en el régimen jurídico vigente otra norma que regule esa si- 
tuación. ${ }^{30} \mathrm{Si}$ el artículo 2 transitorio del CA ha permanecido vigente por más de treinta años se ha debido a la inexistencia de un plazo de cierre para su aplicación; de ahí que hoy permanece abierta la posibilidad de recurrir a la vía procedimental que tal disposición legal consagra, y ello será así mientras no sea derogada o modificada por otra ley.

ii) Señala la Corte, de un modo superficial, casi coloquial, sin fundar en derecho su aserto, que habrían transcurrido "demasiados" años desde 1981, olvidando que la ley no establece plazo para la regularización. Se agrega así a las sentencias una opinión no jurídica, voluntarista, del puro sentimiento y la impresión que le causa al juez el hecho de haber transcurrido ¡tanto! tiempo desde 1981 hasta ahora como para que se siga utilizando esta herramienta regularizadora. Los autores de esas sentencias tienen la errónea impresión de que por el transcurso del tiempo se hubiese producido el efecto de hacer "desaparecer" el mandato legal, lo que es contradictorio con la plena vigencia de ese artículo 2 transitorio del CA según ya se señaló. Esto es gravemente equivocado de parte de la Corte, pues deja de aplicar una norma vigente sin un fundamento jurídico plausible, sino en base a una pura intuición no contrastada con la información fidedigna de tratarse de una ley plenamente vigente.

iii) El extremo del giro jurisprudencial es que, según la Corte, el solicitante actual debería probar un uso "personal", tanto en 1981 como ahora; esto es in personam, olvidando esos redactores que el derecho de aguas es un derecho real y que esa exigencia - inventada y fruto de la pura fantasía de la Corte- es absolutamente imposible en el caso de personas jurídicas.

Pareciera que hay pura intuición y falta de argumentos razonables en estas sentencias. En efecto, el artículo 2 transitorio del CA establece varios requisitos, pero estas sentencias han creado uno nuevo para rechazar las regularizaciones: que el uso exigido con anterioridad a 1981

${ }^{30}$ Como es sólito en la doctrina de la materia, esta "transitoriedad" del artículo 2T del Código de Aguas no tiene nada que ver con una especie de caducidad de esa norma de ley, como si estuviese sometida a una eventual extinción. Esta transitoriedad, como lo dice con razón Luis Simón Figueroa del Río, Asignación y distribución de las aguas terrestres (Santiago: Universidad Gabriela Mistral, 1995), 74, "se debe a que desde su vigencia no se pueden crear nuevos hechos regidos por él, ya que el empleo de las aguas tuvo que iniciarse antes". 
debiese ser realizado "personalmente" por un mismo individuo y, además, mantenerse ese uso personal en la actualidad (aun cuando hayan transcurrido 35 años). Nada indica que la ley haya exigido eso; sería por lo demás completamente desajustado a la calidad de "real" (esto es, no personal) del derecho de aprovechamiento de aguas, e imposible de cumplir para quienes no tengan su domicilio en el lugar de uso de las aguas.

Se afirma: "Es necesario que el solicitante de regularización haya hecho uso personal del derecho de aprovechamiento de aguas" (sic). ${ }^{31}$ Esto es una lectura errónea del artículo 2 transitorio del CA, pues se refiere textualmente a la "utilización" (ejercicio) del derecho y no a un supuesto "uso personal" (¿físico?) de las aguas.

Este criterio de exigir el uso personal al mismo solicitante de regularización no parece razonable ni ajustado a la realidad de las cosas. Sus consecuencias serían las siguientes: en el caso de que una persona natural, propietaria de un inmueble, respecto del cual se haya "reconocido" un derecho de aguas en 1979 (DL 2.603), 1980 (Constitución) y 1981 (CA), si falleciera con posterioridad, siguiendo el increíble criterio de esas sentencias ya no podrían ser regularizados esos derechos de aguas y se perderían irremisiblemente. Como quien fallece ya no podrá seguir usando tales aguas "personalmente" — como lo requiere ahora la Corte Suprema - tal derecho cabría darlo por "irregularizable", pues sus herederos nunca podrán probar un uso "personal" de las aguas en 1981. En el caso de que la propiedad inmueble en que se usaban las aguas fuese una persona jurídica o una comunidad (una comunidad hereditaria, por ejemplo) se llegaría al absurdo de que, como el uso no es "personal", también cabría declarar esos derechos como irregularizables.

Es relevante recalcar que el artículo 2 transitorio del CA es una regla de mera "formalización", no de "existencia" o de "legitimación" del derecho. Si bien, por certeza, es conveniente que los derechos consuetudinarios se formalicen o regularicen, cabe consignar que la ley vigente no lo exige perentoriamente ni establece plazo alguno, ni sanción a su falta, ni contempla caducidad o extinción por no regularizar. Los únicos requisitos son los señalados en el artículo 2 transitorio del CA entre los cuales no aparece la exigencia de un uso "personal”, ni para el año 1981 ni al momento de solicitar tal regularización.

${ }^{31}$ Considerando 18, caso "Inversiones y Asesoría FTM" (2015), copiado en todas las sentencias que siguieron esta jurisprudencia. 
Este inusitado cambio jurisprudencial vino a borrar la doctrina del famoso caso "Chusmiza" (2009), a través del cual la Corte Suprema, precisamente en función de la aplicación de los artículos 7 DL 2.603 de 1979 y 2 transitorio del CA, reconoció los derechos de aguas de los indígenas, basados en el uso ancestral o consuetudinario, a los que en ningún caso se les exigió el desajustado criterio del uso "personal" de las aguas.

\subsection{El efecto no extintivo de este criterio jurisprudencial}

Lo que producen estas sentencias, al denegar la posibilidad de regularizar o formalizar los derechos consuetudinarios, es incerteza; sin embargo, no tienen efectos extintivos en los derechos consuetudinarios de aguas. Queda entonces la siguiente tranquilidad — relativa - para los perdidosos en estas causas: el hecho de que estas sentencias hayan rechazado la posibilidad de "regularización" de estos derechos consuetudinarios no implica, ni podrá implicar nunca, un efecto extintivo de los mismos derechos. Aquellos titulares de derechos de aguas a los que la Corte Suprema les impidió regularizar sus títulos pueden seguir legítimamente usando las aguas de un modo consuetudinario, pues el desconocimiento al estatuto jurídico de los derechos de aguas consuetudinarios que la Corte Suprema realiza sólo está impidiendo que sean regularizados; esto es, los está condenando a mantenerse en su situación de "informalidad". Sus titulares podrán continuar usando las aguas, legítimamente, como lo vienen haciendo desde hace décadas - como es el caso de miles de agricultores, indígenas y particulares - , en virtud de una fuente del derecho que la Corte Suprema ha olvidado en sus sentencias aquí cuestionadas: la costumbre.

Por lo demás, esta regularización se podría reintentar en cualquier instante al no tener ese trámite plazo legal ni caducidad alguna asociada. Ningún efecto tendrá aquí la cosa juzgada de estas sentencias, que vale para el intento regularizador frustrado; pero no priva de uno futuro a sus titulares. En otras palabras, estas sentencias de la Corte Suprema no tienen un efecto extintivo de esos derechos de los particulares, los que están garantizados por la Constitución. Ni esas sentencias lo declaran así, ni podrían declararlo. En este sentido, los jueces que firmaron estas inesperadas sentencias pueden respirar tranquilos, pues su error no ha privado (sin indemnización, como lo garantiza la Constitución) de sus derechos a los usuarios de aguas que en estos casos intentaban 
regularizar o formalizar. Tales solicitantes sólo han perdido su tiempo y recursos al intentar en una ocasión formalizar o regularizar sus derechos nacidos de la costumbre. Podrán seguir usando las aguas como lo han hecho hasta ahora, pero dudarán de aventurarse a un nuevo procedimiento regularizatorio; de igual modo que lo están dudando todos aquellos que han conocido la noticia de estas sentencias.

Pues ese efecto disuasivo a regularizar es precisamente una consecuencia que ya está produciendo la equivocada línea jurisprudencial. Esto es exactamente lo contrario a lo que se señala en algunos considerandos de estas sentencias (sin darse cuenta de lo equivocado de tal argumento). Igualmente dañino es el hecho de condenar estos derechos a la informalidad, pues les está privando de certeza o seguridad jurídica. Esa incerteza en general no es un problema práctico en aquellos casos en que el aprovechamiento de las aguas se produce de manera colectiva, a través de una bocatoma común y bajo la distribución de una organización de usuarios, pues la certeza se la proporcionan recíprocamente los usuarios consuetudinarios entre sí. El problema mayor se producirá en el caso de los usuarios individuales. Sus efectos son similares a la anarquía o al vacío regulatorio; una paradoja en vista de que dichas sentencias parecen buscar certeza, pero es precisamente lo que no producen.

\subsection{La pervivencia de los derechos no formales}

En caso de que los usos consuetudinarios de aguas no lleguen a regularizarse, esa falta de formalización (inscripción) que se mantiene no afecta su subsistencia. En efecto:

i) Pueden seguir siendo protegidos mediante las acciones posesorias típicas de toda posesión (reguladas en el Código Civil y en el Código de Procedimiento Civil), así como la acción especial de amparo que contiene el Código de Aguas y la acción constitucional de protección (art. 20 de la Constitución).

ii) Los derechos consuetudinarios, dado que son reconocidos por la ley y la Constitución, no se extinguen ni podrían extinguirse por la falta de regularización o formalización (ni por la subsecuente falta de inscripción), pues la falta de regularización no es causal de extinción.

De ahí que respecto de los usos consuetudinarios cabe distinguir: por una parte, su existencia, pervivencia y reconocimiento, y, por otra, 
su regularización. Aquello es esencial; esto es un accesorio, importante para la certeza, pero no para su subsistencia.

La plena existencia y ejercicio actual de miles de derechos, surgidos en usos consuetudinarios, reconocidos y protegidos por la ley y la Constitución es la prueba más fehaciente. A esos derechos les prestó protección tradicionalmente la antigua línea jurisprudencial.

\section{ESTADÍSTICA DE VOTOS DE MINISTROS Y ABOGADOS INTEGRANTES (2014-2018) EN CAUSAS DE REGULARIZACIÓN DE DERECHOS DE AGUAS}

El cambio jurisprudencial deja de manifiesto una dispersión en la materia que se comprueba al revisar las votaciones individuales por parte de ministros y abogados integrantes. ${ }^{32}$ De la observación de esas conductas quizás sea posible obtener alguna explicación de las vacilaciones institucionales que muestra la Corte Suprema como órgano jurisdiccional.

\subsection{Aumento de la conflictividad en la materia}

La revisión de los datos que se exponen considera todas las causas relativas a la regularización que han sido recopiladas, en un periodo que abarca desde 2004 a 2014 (primer período) y desde diciembre de 2014 a agosto de 2018 (segundo período). El resultado, una vez revisadas las bases de datos digitales de jurisprudencia de esos dos períodos, refleja que la Corte Suprema se ha pronunciado en un total de 38 ocasiones sobre la suma de posesiones en la regularización de derechos consuetudinarios de aguas. En el primer período, de casi una década, hubo sólo 15 sentencias relativas a la regularización; en el segundo período, de tan solo tres años y medio, el número prácticamente se duplicó. Esto ciertamente da señales del aumento de conflictividad en la materia.

${ }^{32}$ En esta parte he contado con la colaboración de Nicole Ávila Meza, abogada de la Pontificia Universidad Católica de Chile (UC), diplomada en derecho de recursos naturales, mención aguas, e investigadora del Centro de Derecho y Gestión de Aguas de la UC. Ella ha estado a cargo de la recopilación de jurisprudencia y análisis de votos para la generación de gráficos, de lo cual le estoy muy agradecido. Debo reconocer además que el análisis jurisprudencial fue posible gracias a la recopilación de sentencias de la materia de aguas, dictadas por las cortes de apelaciones y Corte Suprema entre 2006 y 2016, realizada por dicho Centro de Derecho y Gestión de Aguas. 
Gráfico 2. CIFRA TOTAL DE SENTENCIAS DE REGULARIZACIÓN HASTA AGOSTO DE 2018

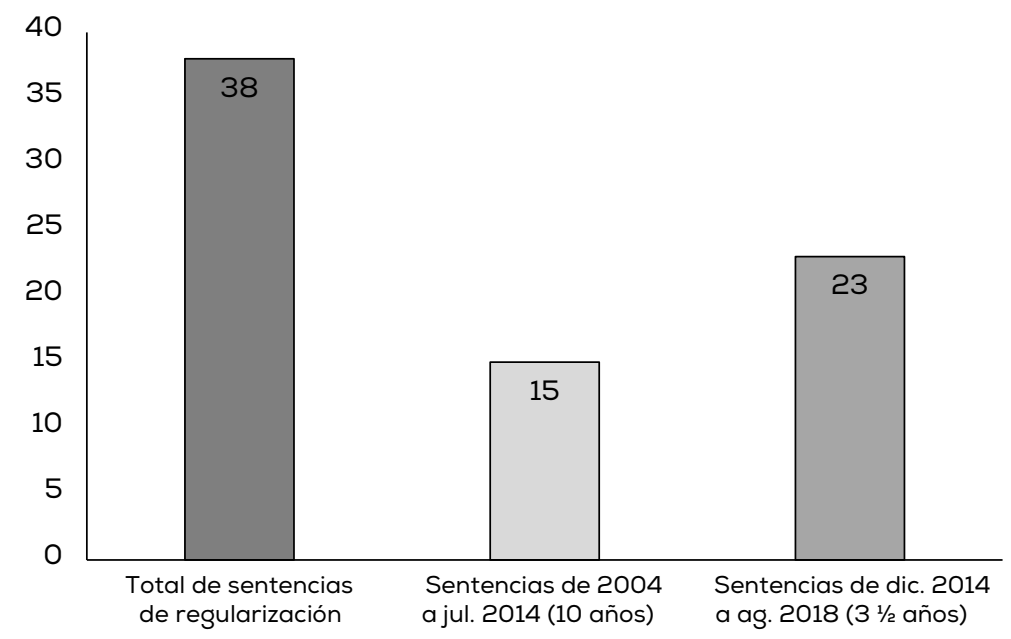

\subsection{La unanimidad se altera en 2014}

La unanimidad o las disidencias son indicativas de lo arraigada o no que se encuentra una tendencia jurisprudencial en la Corte Suprema. Hasta 2014 había sólo unanimidad y es en el año 2014, junto con el cambio jurisprudencial, que se comienzan a producir las disidencias. Así, al revisar los dos períodos, aparece que todas las sentencias del primer periodo (2004 a 2014) aceptan de manera unánime la suma de posesión en la regularización ${ }^{33}$ (gráfico 1). Por el contrario, en el segundo periodo, sólo en 5 ocasiones se aceptó la regularización, versus 18 rechazos, y con múltiples votos disidentes (gráfico 3).

En el período de diciembre de 2014 a agosto de 2018, más de un tercio de las sentencias (37,5 por ciento) se decidieron por unanimidad, y casi dos tercios (62,5 por ciento) se decidieron con al menos un voto de disidencia. La disidencia es liderada consistentemente por la ministra Egnem y por el ministro Muñoz.

33 Sólo una sentencia del primer período presenta dos votos disidentes; sin embargo, dichos votos no dicen relación con la suma de posesiones, sino con un motivo diverso que no altera este análisis. 
Gráfico 3. DECISIONES UNÁNIMES O CON DISIDENCIAS SOBRE REGULARIZACIÓN EN CORTE SUPREMA DESDE DICIEMBRE 2014 A AGOSTO $2018^{34}$

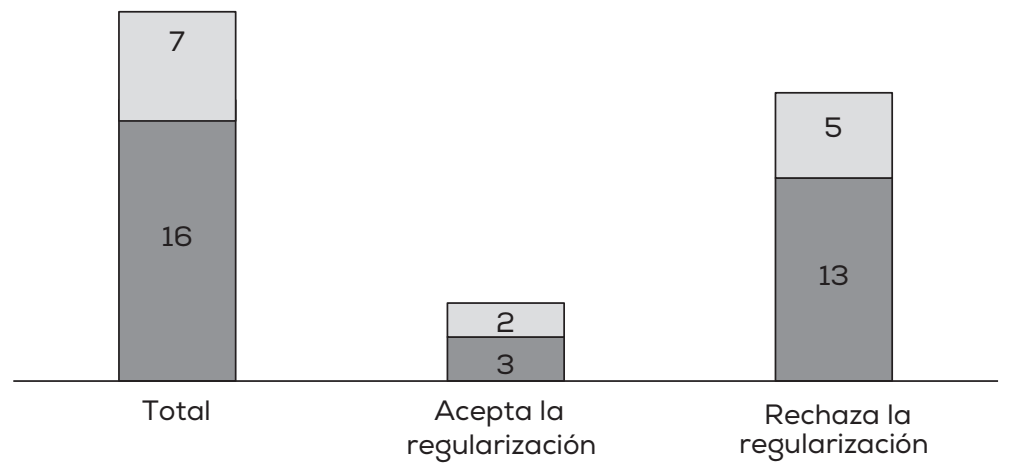

Con disidencia $\square$ Con unanimidad

El gráfico 3 también muestra que en los casos en que la Corte $\mathrm{Su}-$ prema ha rechazado la regularización de derechos de aguas hay una alta proporción de causas con disidencia y una baja proporción de causas unánimes.

De este simple ejercicio es posible evidenciar la clara tendencia existente con anterioridad a 2014, en cuanto a la unanimidad para aceptar la accesión de posesión en la regularización de derechos consuetudinarios de aguas. Este patrón se condice con una de las tesis sostenidas por uno de los pocos estudios referidos a las conductas de los jueces de la Corte Suprema chilena. ${ }^{35}$ Pardow y Carbonell estudian las coaliciones de la Tercera Sala, y muestran que el 90 por ciento de sus sentencias se decide por la unanimidad de la sala. Pero en la materia de aguas que reviso en este recuento tan alto porcentaje de sentencias unánimes sólo ocurrió hasta diciembre de 2014 , etapa en que el porcentaje de disidencia cambia y se sitúa en $69,6 \%$, al punto de equipararse con la realidad

${ }^{34}$ Véase en los anexos 9.7 y 9.8 los casos específicos en que las sentencias son unánimes o con disidencias, con el detalle de los ministros y abogados integrantes que fallan a favor o en contra.

${ }^{35}$ Diego Pardow y Flavia Carbonell, "Buscando al juez mediano: estudio sobre la formación de coaliciones en la Tercera Sala de la Corte Suprema", en Revista de Ciencia Política (2018, en prensa). 
norteamericana, ${ }^{36}$ ya que los votos disidentes de la Corte Suprema de ese país alcanzan el 62 por ciento.

\subsection{La dispersión de votos de ministros y abogados integrantes en el tema}

Con el fin de observar la conducta de los jueces en este tema, en los siguientes gráficos se han desglosado las votaciones de cada sentencia en votos unitarios por cada ministro o abogado integrante (AI), para así determinar el número de participación que ha tenido cada uno e identificar a aquellos jueces presentes en ambos períodos en sus respectivas votaciones. En el gráfico 4, aparecen todos los ministros y abogados integrantes que intervinieron en alguna causa de la temática, con indicación del número de votos (y participación) que han tenido en el período 2004-2014.

Es posible observar la clara y contundente tendencia a aceptar la accesión de posesión en la regularización, incluso por parte de ministros que sólo tuvieron una única oportunidad de fallar esta materia. Destacan por tener una mayor participación en estas causas durante este primer período los ministros Segura, Silva, Rodríguez, Araya, Dolmestch y Ballesteros. Existe, así, una total aceptación a la suma de posesiones en la regularización en el primer período jurisprudencial.

Eso cambia en el período siguiente. El gráfico 5 contiene las votaciones de todos los ministros y abogados integrantes intervinientes en causas relativas a la temática tratada desde diciembre de 2014 a mayo de 2018.

\subsection{Ministros que cambian sus votos}

Aun cuando se ha señalado que la ministra Egnem ha sido la más consistente disidente frente a la nueva tendencia, de igual manera lo hace el ministro Muñoz, a pesar de un único caso, de finales de 2017,

${ }^{36}$ Lee Epstein, William Landes \& Richard Posner, Why (and when) Judges Dissent: A Theoretical and Empirical Analysis (John M. Olin Program in Law and Economics Working Paper No. 510, 2010). En este trabajo, los autores estudian por qué los jueces de una Corte Suprema altamente politizada como la norteamericana disienten, tomando como base de estudio las sentencias con disidencia de tres años diferentes, correspondientes a tres presidencias de la Corte Suprema distintas. Estimando el porcentaje de resoluciones con disidencias en 62 por ciento. 
Gráfico 4. PERÍODO DE UNANIMIDADES, DESDE 2004 A JULIO 2014. NÚMERO DE VOTOS TOTALES DE CADA MINISTRO Y ABOGADO INTEGRANTE (AI)

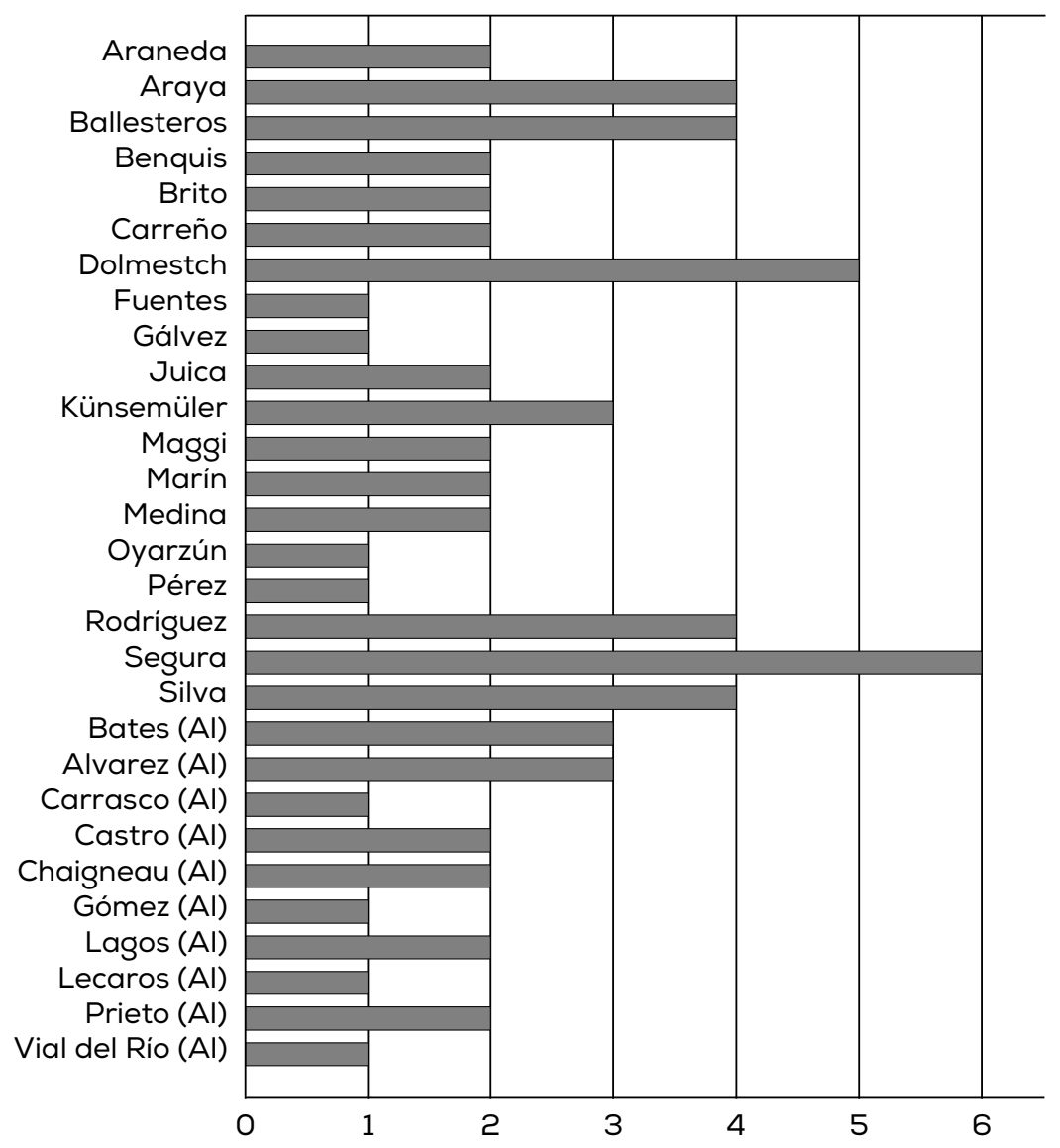

en el cual emite por primera vez un voto en contra de la regularización. ${ }^{37}$ El que primero fue abogado integrante y luego, a partir de 2017, ministro Prado y el abogado integrante Quintanilla cambian sus votos una y otra vez, de manera dispersa y zigzagueante. La ministra Sandoval emite dos votos a favor en sendas causas en que opera una tendencia pro indígena; una decidida por unanimidad (caso "Mulluri", 2017)

37 Ver causa "Mario Medina con DGA" (2017). Pareciera ser una inadvertencia del ministro Muñoz, pues es contradictorio con todas las demás sentencias, prevenciones y disidencias en que claramente se muestra favorable a la tendencia tradicional. 
Gráfico 5. PERÍODO DE VACILACIONES, DESDE DICIEMBRE 2014 A AGOSTO 2018. NÚMERO DE VOTOS TOTALES DE CADA MINISTRO Y ABOGADO INTEGRANTE (AI)

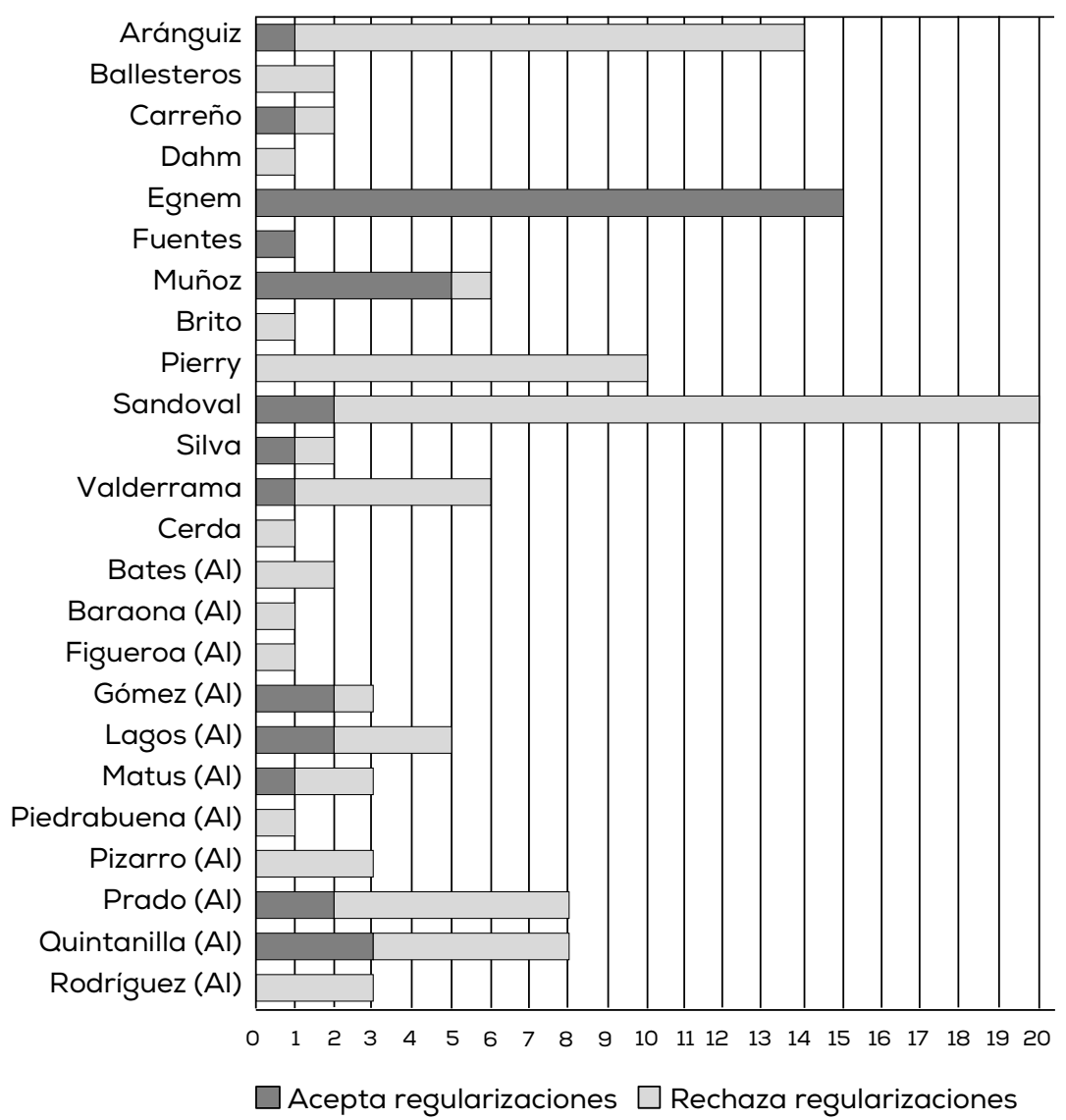

y otra por mayoría ("Toconce con SQM", 2018). Existen ministros que han intervenido en ambos períodos; a saber, los abogados integrantes Bates, Gómez, Lagos y Rodríguez, y los ministros Brito, Ballesteros, Carreño, Silva y Fuentes. Su conducta se muestra a continuación en los gráficos 6 y 7 .

Ambos gráficos (números 6 y 7) muestran el cambio que ha existido en la posición sostenida por estos ministros, especialmente porque es posible ver que en el primer período (gráfico 6) todos votaron exclusivamente aceptando la suma de posesión en la regularización, y en el segundo período aparecen votando en contra. Los ministros Brito, Ballesteros y los abogados integrantes Rodríguez y Bates pasan de emitir 
votos sólo a favor (hasta 2014) a votar sólo en contra, en tanto que los ministros Carreño y Silva y los abogados integrantes Gómez y Lagos siguen emitiendo alguno que otro voto a favor. Sólo el ministro Fuentes está en ambos periodos con un voto a favor de aceptarla.

Gráfico 6. PERÍODO DE UNANIMIDADES, DESDE 2004 HASTA JULIO 2014. SÓLO VOTACIONES DE MINISTROS Y AI PRESENTES EN AMBOS PERIODOS

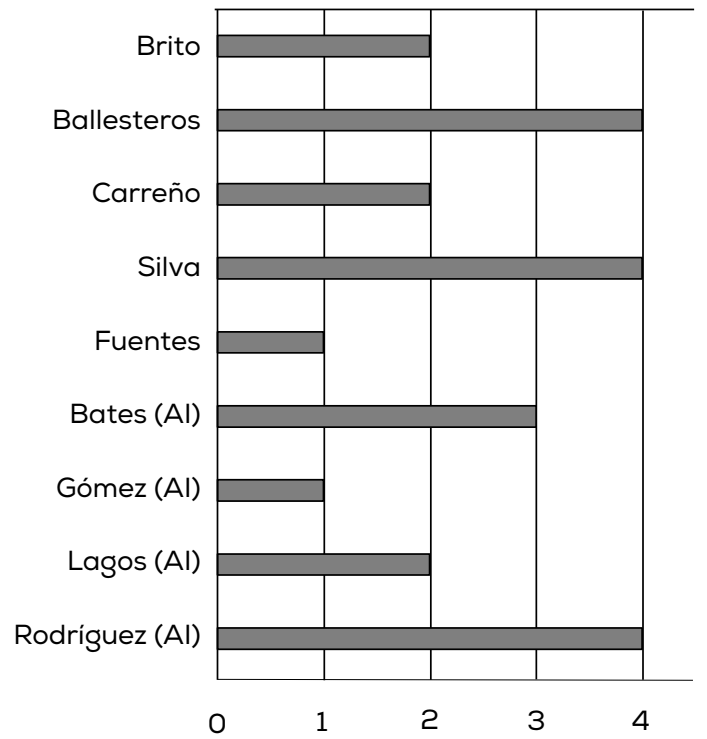

$\square$ Acepta regularizaciones $\square$ Rechaza regularizaciones

La Tercera Sala, en el caso "Mulluri" (2017), altera su propia tendencia fallando a favor de la regularización por la unanimidad de sus ministros; a saber, Sandoval, Aránguiz, Muñoz, Valderrama y el abogado integrante Quintanilla, quienes en su mayoría rechazan la suma de posesión en las regularizaciones de derechos consuetudinarios de aguas, salvo el ministro Muñoz, quien en el análisis de comportamiento judicial ha sido de una tendencia afín a permitir la suma de posesión para todo tipo de solicitantes (individuos indígenas o no indígenas). Este fenómeno podría deberse al hecho de ser esos ministros de la mayoría "seguidores" del razonamiento o votación de los ministros que lideran la sala, especialmente en el segundo período, y que parece ser encabe- 
zado por los ministros Sandoval, Pierry y Aránguiz ${ }^{38}$ (si bien en este caso imperó el criterio pro indígena, como muestro más adelante).

Gráfico 7. PERÍODO DE VACILACIONES, DESDE DICIEMBRE DE 2014 HASTA AGOSTO 2018. VOTACIONES DE MINISTROS Y AI PRESENTES EN AMBOS PERIODOS

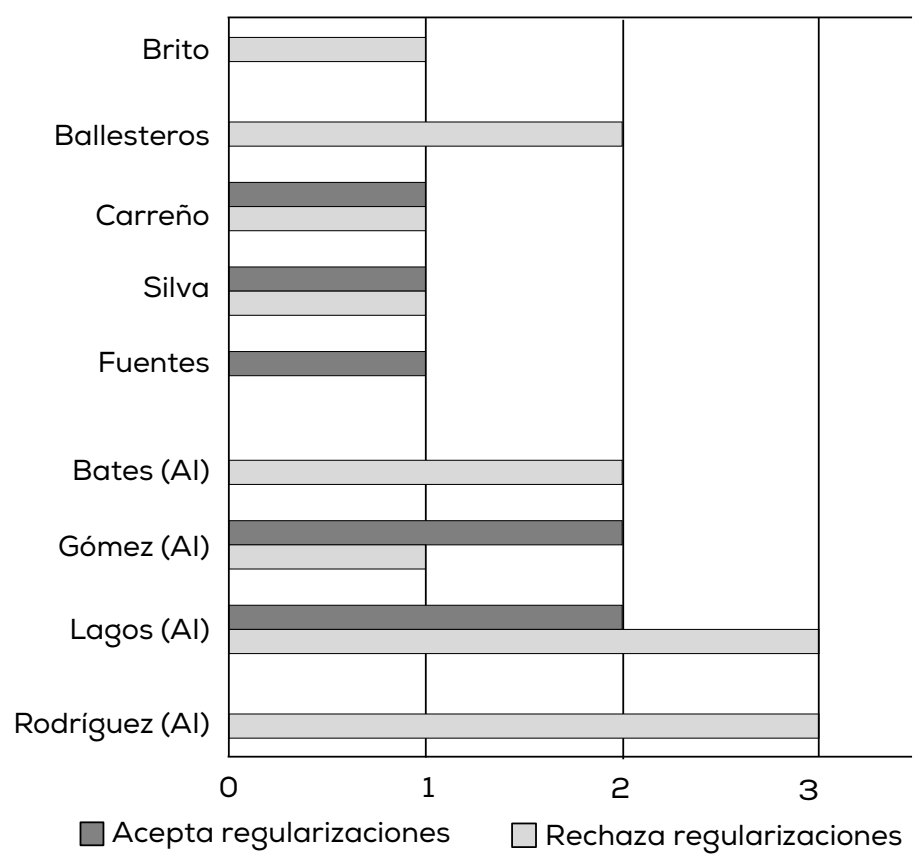

5.5. La conducta de los abogados integrantes

Sobre la posible incidencia de los abogados integrantes de la Corte Suprema en este constante zigzagueo, de la revisión de los gráficos es posible ver que en el segundo periodo los abogados integrantes que zigzaguean en su votación son Prado (hasta 2017), Quintanilla, Gómez, Lagos y Matus.

En el caso de Prado, votó en siete oportunidades, dos aceptando la regularización y rechazándola en cinco; él formó parte de la mayoría en seis casos y sólo en una fue minoría (en 2018 junto a la ministra Egnem). Además, en "Vera Urra" (2017) pareciera haber sido factor decisivo, pues se encuentra entre la coalición Sandoval-Aránguiz (am-

${ }^{38}$ Según las conclusiones de Pardow y Carbonell, "Buscando al juez". 
bos siempre votan en contra), y la coalición Egnem-Muñoz (ambos a favor), uniéndose a estos últimos en esa ocasión. Sin embargo, siempre que estaba la coalición Pierry-Sandoval (ambos siempre en contra), Prado se unía a ellos, como si fuese seguidor de Pierry, zigzagueando así constantemente.

En el caso de Quintanilla, ha votado tres veces a favor y cinco en contra, siendo parte de la mayoría siempre, dando la impresión de ser un mero seguidor. Gómez, por su parte, votó en tres ocasiones, dos a favor y una en contra, siendo parte de la minoría en las tres ocasiones, dos con Egnem y una con Pierry. Finalmente Lagos ha votado en cinco ocasiones, dos a favor y tres en contra, con cuatro mayorías y una minoría (junto a la ministra Egnem). Los otros abogados integrantes del periodo no han sido revisados, pues han sido consistentes en el rechazo a la regularización sin mostrar un vaivén en sus decisiones. Ciertamente un análisis de la incidencia de estos abogados integrantes entre coaliciones daría para un estudio en sí mismo.

\section{A LAS COMUNIDADES INDÍGENAS NO LAS AFECTA LA NUEVA TENDENCIA}

Un comportamiento pro indígena se ha manifestado en los casos "Mulluri" (2017) y "Toconce" (2018), en donde aparecen cuatro ministros y dos abogados integrantes de tendencia opositora ahora a favor de la suma de posesión en la regularización, aceptándola ahora, es evidente, por el mero hecho de tratarse de una comunidad indígena. Esto es muy notorio en "Mulluri" (2017), en que la sentencia ni siquiera se detiene a analizar el hecho del uso personalísimo tan ampliamente defendido por los mismos ministros firmantes en el resto de las causas desde 2014; tampoco sin entrar al análisis de la existencia de la suma de posesiones en el caso, y reconociendo, en cambio, explícitamente una posesión anterior e inmemorial de las aguas por parte de los indígenas y sus antecesores, con total inconsistencia con los otros fallos firmados por ellos mismos. En "Toconce” (2018), la redacción de la sentencia es cuidadosa y fundamentada, y evita esa incoherencia tan patente en "Mulluri"; se esfuerza en fundamentar ahora su criterio pro indígena mediante una desarrollada argumentación, en base a la aplicación de las disposiciones relativas a aguas de la Ley Indígena, logrando una correcta sentencia. Se distancia el críptico, escueto e infundado voto 
Gráfico 8. LA TENDENCIA PRO INDÍGENA. VOTACIONES DESDE DICIEMBRE 2014 DE LOS MINISTROS PARTICIPANTES EN LOS CASOS "MULLURI" (2017) Y "TOCONCE" (2018)

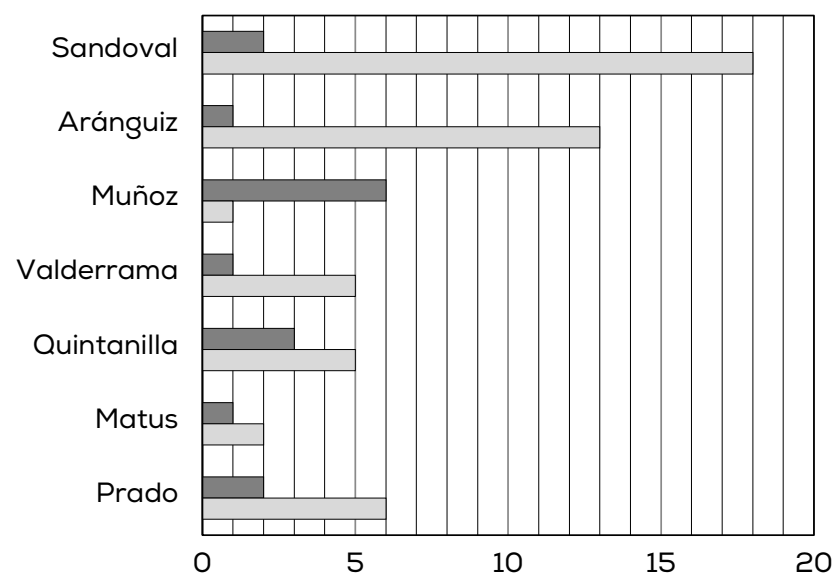

$\square$ Acepta regularizaciones $\square$ Rechaza regularizaciones

del ministro Prado. Esto se muestra en el gráfico 8, que incluye sólo las votaciones que han tenido los ministros intervinientes en los casos "Mulluri" (2017) y "Toconce" (2018) a favor del criterio que llamo pro indígena.

Cabe señalar que de no ser por la presencia del ministro Muñoz, quien aporta seis votos a favor de la suma de posesión aceptando la regularización, todos los otros integrantes se han opuesto a la regularización en muchas ocasiones: desde dos veces (en el caso del AI Matus), hasta cinco, seis, trece y dieciocho veces (en el caso de la ministra Sandoval). Pareciera que nos encontramos meramente ante un fallo pro indígena, y que no sería entonces una tendencia a seguir para el resto de las causas "no indígenas". El origen de la tendencia anterior a 2014, en que se aceptaba la accesión de posesión, quedó marcado precisamente por una causa de usos de aguas de indígenas: "Toconce" (2004). Ella fue después reforzada por otra causa de usos de aguas de indígenas: "Chusmiza" (2009), si bien en esa época se fallaban de manera pareja los casos de usos de aguas tanto de indígenas como de usuarios no indígenas.

Pareciera que se trata de un criterio pro indígena larvado, que es usual en la jurisprudencia de la Corte Suprema de Estados Unidos, en que se suele aplicar pero de un modo ostensible: es un "principio de derecho" 
dirigido a favorecer a los indígenas. ${ }^{39}$ Lo característico de este evidente criterio pro indígena es la falta de explicitación o reconocimiento directo del mismo por parte de la Corte Suprema chilena, pues en apariencia se aplican las mismas reglas generales, pero no se las sujeta al zigzagueo observable en causas de agricultores u otros usuarios no indígenas.

El tema de la tendencia o principio jurídico pro indígena puede deberse al estatuto jurídico especial que tienen las poblaciones indígenas a nivel internacional como grupos sujetos de protección, toda vez que son reconocidos como vulnerables y susceptibles de discriminación. Por lo mismo, el Convenio 169 de la OIT establece en el artículo 2 que es responsabilidad de los gobiernos desarrollar acciones para proteger los derechos de esos pueblos, y el artículo 15 establece que los derechos de estos a los recursos naturales en sus tierras deberán protegerse especialmente. Esto se une al artículo 64 de la Ley Indígena, que establece la especial protección de las aguas de las comunidades aimaras y atacameñas. ${ }^{40}$ Ello haría pensar que efectivamente las comunidades indígenas se encuentran en una posición favorable y la Corte Suprema pareciera tenerlo muy presente. Además, la Comisión Interamericana de Derechos Humanos, en un documento sobre el acceso al agua en las Américas, se refiere bastante a la situación del acceso al agua de las comunidades indígenas, mostrando jurisprudencia de la Corte Interamericana en la que se reconoce el derecho de los integrantes de pueblos indígenas y tribales a ser titulares de los recursos naturales que han usado tradicionalmente dentro de su territorio, de la misma forma en que tienen derecho a ser titulares de la tierra que han usado y ocupado tradicionalmente. ${ }^{41}$

${ }^{39}$ Cass Sunstein, After the Rights Revolution: Reconceiving The Regulatory State (Cambridge: Harvard University Press, 1990). Cito según traducción: La revolución de los derechos: Redefiniendo el Estado regulador (Madrid: Editorial Universitaria Ramón Areces, 2016), 183.

${ }^{40}$ Lo que a juicio de un autor las desafecta del régimen general de las aguas como bienes nacionales de uso público. Así opina Rodrigo Muñoz, "Aguas Indígenas: Categoría excepcional”, Revista de Derecho Administrativo Económico 3, n. ${ }^{\circ} 2$ (2000): 425-428. Pero eso no es lo que ocurre, pues las aguas siguen siendo bienes públicos, y de lo que se trata es de un "reconocimiento" de derechos de aguas de los indígenas, lo que no muda la naturaleza de las aguas como públicas; como lo digo y fundamento en Vergara, "Estatuto jurídico", 181.

${ }^{41}$ Ver Capítulo IV. A, "Acceso al agua en las Américas. Una aproximación al derecho humano al agua en el sistema interamericano", en Informe Anual 2015, del CIDH. 


\section{UNA REFLEXIÓN SOBRE LA CONDUCTA JUDICIAL VACILANTE}

La crítica de fondo a una línea jurisprudencial es algo usual en la literatura propiamente jurídica; de ahí que en este escrito analizo los argumentos que se desarrollan en las sentencias respectivas. A ello dedico buena parte de este trabajo. Pero, además, agrego algunos gráficos que permiten una observación y comprobación estadística de la conducta muchas veces errática de los ministros y abogados integrantes de la Corte Suprema en este tema. Estas vacilaciones de la jurisprudencia se contraponen con la necesidad de buscar una política de precedentes, que permita cierta predictibilidad. Ello se conecta con los análisis etnográficos o de sociología judicial. Sólo entrego la evidencia estadística y algunas razones para preferir una jurisprudencia de precedentes, dado que permite una cierta predictibilidad. ${ }^{42}$

\subsection{El minusvalor democrático de una jurisdicción vacilante y sin precedentes constantes}

El pleno de la Corte Suprema suele ser muy activo aprobando diversas "políticas" a través de diversos auto acordados, los que abarcan distintas materias. Tales políticas son definidas por la propia Corte como marcos de actuación para todos los jueces y tribunales, unipersonales y colegiados (pues cabe recordar que cada sala de la Corte Suprema es en sí misma un tribunal). Quizás una política que promueva una jurisprudencia en base a precedentes constantes, que no dañe la independencia de cada juez, sería un gran aporte a la democracia, la que clama por la igualdad ante la justicia, hoy gravemente quebrantada en los casos que muestro en este trabajo. Ello pareciera que es la principal conclusión que es posible obtener cuando se estudia la regularización de los derechos consuetudinarios de aguas ante la jurisprudencia.

No debe confundirse la tradicional "independencia" que todos los jueces invocan con el rol democrático y garantista de las respuestas jurisdiccionales coherentes que espera la sociedad. Pues lo que cabe evitar es un escenario de sentencias cambiantes, vacilantes o zigzagueantes.

42 Tema recurrente entre nosotros, a tal punto, que el nuevo presidente de la Corte Suprema, para del período 2018-2020, Haroldo Brito, en su primera entrevista, señaló: "La predictibilidad de la resolución (...) es una cuestión particularmente deseable" (El Mercurio C-4, 1 de marzo de 2018). Dicha predictibilidad, resulta obvio, es lo opuesto al zigzagueo que se observa en esta materia. 
Esa independencia que invoca cada juez para fallar según su conciencia no puede transformarse en un lamentable espectáculo de constantes zigzagueos respecto de sus propios votos anteriores en causas idénticas. La tolerancia por parte del propio pleno de la Corte Suprema de estas conductas, al no regular de algún modo estas "espontaneidades" de sus ministros y abogados integrantes, se ha transformado en alguna medida en una suerte de descuido jurisdiccional del valor de los precedentes o de la necesidad de una jurisprudencia constante. Pues cabe distinguir los deberes jurisdiccionales del Poder Judicial (que son notorios en la actividad del pleno de la Corte Suprema) de los deberes jurisprudenciales (que reposan en cada juez o en cada tribunal). La jurisdicción (esto es, la actividad global de los jueces) se basa en dos ideas matrices: la exclusividad y la inexcusabilidad con que deben resolver todo tipo de conflictos. ${ }^{43}$ En base a ellas se logra el mayor aporte que los jueces ofrecen cada día a la sociedad democrática: su pacificación. Hay algunas virtudes en las respuestas que se espera de los jueces: que sean prontas, que no haya prejuzgamiento según sean las partes, que haya independencia, etcétera. Pero entre medio existe una necesidad, paralela con la virtud de la justicia: la certeza. Pues, cuando las respuestas de los tribunales son consistentes o similares, surcando una línea o un camino de precedentes, y si son mantenidas en el tiempo parecieran lograr el ideal de la coherencia institucional, y de ese modo interpretan mejor al pueblo, produciendo en la sociedad una sensación de tranquilidad. Eso es lo que se espera de la conducta de los jueces. Pero lo que producen los cambios repentinos y zigzagueantes de jurisprudencia es la sensación contraria, de intranquilidad. Incluso de desconfianza institucional.

Si bien formalmente en nuestra tradición jurídica no se ha desarrollado una cultura de precedentes (sobre todo a partir de una lectura errónea del artículo 3 inciso 2 del Código Civil y una noción excesiva de la independencia de cada juez), ${ }^{44}$ ello podría ser recomendable. Una juris-

${ }^{43}$ La exclusividad es la base de la autonomía judicial, pues sólo a los tribunales corresponde el rol de poner término de modo irrecurrible a los conflictos que ocurren en nuestra sociedad. La inexcusabilidad obliga a los jueces a resolver todos los conflictos que llegan a su conocimiento. No pueden, pues, excusarse de dictar sentencia "ni aun por falta de ley", dice la Constitución.

${ }^{44}$ El artículo 3 inciso 2 del Código Civil señala: "Las sentencias judiciales no tienen fuerza obligatoria sino respecto de las causas en que actualmente se pronunciaren", pero pareciera que ello está dirigido a las partes y a los justiciables en general, lo que no obsta a una cultura de precedentes; lo mismo sucede con la independencia ministerial de los jueces; temas que sólo menciono y que no puedo profundizar. 
prudencia de precedentes es, en primer lugar, coherente con la igualdad ante el derecho, la que es una garantía constitucional. El hecho de que los diversos particulares, ante unos mismos hechos básicamente idénticos, sean juzgados con una mano judicial distinta, que sean tratados con criterios judiciales diferentes es una evidente afectación a esa garantía. Eso, en términos institucionales, tiene un hálito de arbitrariedad. Los jueces, en especial quienes integran la Corte Suprema, deben intentar evitar cambios bruscos de criterios. Pero los jueces suelen ser vacilantes, y parecieran no darse cuenta que, con ello, rompen un valor y una conducta que se espera de ellos: el respeto de los precedentes. Por ello, cabe observar los efectos que los cambios bruscos de precedentes tienen en la sociedad. Pareciera que la jurisprudencia de precedentes más o menos sostenidos en el tiempo tiene unas consecuencias sociales positivas, y los jueces debieran promoverla. Además, los precedentes dan certeza a los ciudadanos y contribuyen a una más perfecta conciencia de que en democracia la ley no es la única fuente del derecho, si bien es la más importante por su generalidad y posibilidad de coacción y que a ella deben ajustarse los particulares, autoridades y jueces en primer término. Pero la ley, que es un enunciado, un texto, no es autoejecutable, no se ejecuta a sí misma; para que la ley sea carne y espíritu de la sociedad es necesario agregar a la jurisprudencia, que es la que interpreta, aplica o adjudica el derecho legal. Cuando las sentencias de casos individuales son conocidas, a partir de lo que dice de ellas la prensa o por las críticas de los juristas, la sociedad puede conocerlas y tener la sensación de que debe amoldar su conducta a esa interpretación del derecho. Muchas veces lo que dice una sentencia, o una seguidilla de sentencias uniformes (esto es, un precedente), puede ser muy relevante para la conformación del espíritu jurídico que se anida en la sociedad. Y una sociedad va a tener una sensación de mayor certeza del derecho en la medida en que las respuestas jurisprudenciales no sean bruscamente cambiantes.

\subsection{Certeza jurídica y dispersión jurisprudencial en regularizaciones de derechos consuetudinarios de aguas}

Entonces, en materia de regularizaciones de derechos de aguas, no es sólo el criterio de exigir un uso personal de las mismas (criterio impracticable y no exigido por la ley a un derecho real) el que ha provocado 
incerteza jurídica a los usuarios de agua, sino que también la dispersión jurisprudencial en sí misma. En la praxis, los titulares de esos derechos consuetudinarios son empujados habitualmente a formalizar sus derechos, ya sea por la necesidad de lograr mayor certeza registral de los mismos o por impulsos regulatorios; pero paradójicamente la jurisprudencia ha sembrado una doble incerteza: el criterio de fondo y sus vacilaciones.

La aceptación o rechazo de las regularizaciones de derechos de aguas por la Corte Suprema, en causas idénticas, dependen casi únicamente de la integración de la Tercera Sala. Incluso a veces, en causas idénticas, unos mismos ministros se inclinan por uno u otro criterio, sin que hayamos podido descubrir de la lectura de esos fallos las razones jurídicas de esos ministros para justificar esos cambios de parecer. Salvo el criterio pro indígena, que reviso en la sección 6 .

Cabe una mirada autocrítica del mismo órgano jurisdiccional a su conducta, cualquiera que sea la línea jurisprudencial de fondo que prospere, respecto de lo cual la Corte Suprema tiene un mandato democrático que debe respetar, y debiese buscar un mecanismo para evitar vacilaciones constantes. Pero, pareciera que, mientras subsista la figura de los abogados integrantes, junto al cambio permanente en la conformación de las salas y la tolerancia a los zigzagueos constantes e incomprensibles que a veces se observan (lo que queda a la vista en este estudio), ello no será solucionado. Para iniciar el cambio, los ministros de una sala debiesen tener una gran regularidad y permanencia en su integración. De ese modo la conducta institucional de la Corte Suprema estará más acorde con la respuesta democrática que todos esperamos: una conducta de precedentes sin cambios bruscos ni de vacilaciones o zigzagueos constantes.

\section{CONCLUSIONES}

En cuanto al tema de fondo: la accesión de posesiones de derechos de aguas consuetudinarios, puede concluirse que:

i) Los derechos de aguas de agricultores e indígenas, entre otros usuarios rurales, tienden a ser de carácter consuetudinario y costumbrista (por provenir de un conocido factum: el uso de una misma agua, sostenido en el tiempo, tolerado por todos y con la conciencia de cada cual de actuar correctamente. Estos derechos, a partir de un uso mu- 
chas veces ancestral, son reconocidos por la ley y garantizados por la Constitución. Para todos, existe un procedimiento regularizador al que se puede someter el usuario de las aguas (no es obligatorio en la regulación vigente), y que se encuentra contenido en el artículo 2 transitorio del Código de Aguas (CA). Este artículo constituye una herramienta procedimental de ajuste, y requiere dos requisitos: que se trate de un uso efectivo de las aguas, a la fecha de entrada en vigencia del CA (29 de octubre de 1981), y que se hayan cumplido al menos cinco años de uso ininterrumpido, contados desde la fecha en que hubiere principiado.

ii) Hasta julio de 2014 existía una clara tendencia a aceptar la regularización de derechos de aguas en la Corte Suprema, sin importar la integración de la sala que conociera del asunto. Este criterio cambió a partir de diciembre de 2014 con una tendencia a rechazarla, aunque se ha mostrado como una tendencia irregular.

iii) La nueva tendencia que en las regularizaciones de derechos de aguas ha dominado en la Corte Suprema desde 2014 a 2018 ha incorporado la exigencia de uso personal de las aguas (tanto en 1981 como en la actualidad) por el mismo solicitante (criterio impracticable y no exigido por la ley a ningún derecho real). Ello ha provocado incerteza jurídica a los titulares de derechos de agua cuyo título proviene de ese factum propio de nuestro país: de la costumbre o tradición ancestral, derechos éstos que se van transfiriendo o heredando. La notoria dispersión jurisprudencial que se observa al respecto produce en sí misma incerteza a esos justiciables.

iv) Es admirable que los jueces para resolver un caso complejo o en aquellas situaciones en que se perciba la existencia de una "laguna legal" vayan "más allá de las leyes", en pos de un ideal de justicia compartido por la sociedad de su tiempo, esto es, de algún principio jurídico pleno de valores que reemplace la ausencia de ley. Pero esa búsqueda de algún principio o valor no es el imperativo de la conducta de los jueces que han sostenido la nueva línea jurisprudencial en materia de regularización de derechos consuetudinarios de aguas, desde 2014 a 2018, al negar a sus titulares la formalización de sus derechos, sino que lo han hecho - como fluye de los argumentos que deslizan en tales sentencias - simplemente a partir de una "intuición" ("han pasado treinta y cinco años"; "es mucho para una disposición transitoria"), seguida de un error interpretativo. De ahí que esta línea jurisprudencial contra legem ha resultado catastrófica para los titulares de derechos de aguas. 
En cuanto a los aspectos institucionales (zigzagueos y tendencia pro indígena), se puede decir que:

v) La forma en que resuelva la Tercera Sala depende en gran medida de la conformación o integración de la misma, ya que es posible identificar dos bloques opuestos de ministros o abogados integrantes. Así, lideran las mayorías por rechazar la accesión de posesión los ministros Sandoval y Aránguiz. Por el otro lado, los ministros Egnem y Muñoz — aunque desde 2017 se ha agregado el ministro Prado, con algún zigzagueo - aparecen manifestándose a favor de la misma. La aceptación o rechazo de las regularizaciones de derechos de aguas por la Corte Suprema, en causas idénticas, depende hoy, en consecuencia, de la integración de la sala respectiva. Incluso a veces unos mismos ministros se inclinan por uno u otro criterio, sin que hayamos podido descubrir de la lectura de esos fallos las razones jurídicas de esos ministros para justificar el cambio de parecer.

vi) Es curioso que una de las primeras sentencias, al inicio de la línea jurisprudencial tradicional de la Corte Suprema, que aceptaba la regularización de derechos consuetudinarios, haya sido dictada en un famoso caso indígena — “Chusmiza" (2009) — y que, en medio de las últimas vacilaciones, la Corte Suprema haya preferido esa línea en otros casos que resultaron ser pro indígena: "Mulluri" (2017) y "Toconce" (2018). Esta conducta pro indígena es el trasunto de un principio general de derecho creado así por la Corte Suprema, de modo larvado, a beneficio de los indígenas, frente a los cuales claramente se muestra siempre protectora; de ahí que los usuarios de aguas indígenas no han estado expuestos a las vacilaciones de la jurisprudencia como ha sido el caso de los demás usuarios de aguas. Ello es curioso, pues existen ministros que sólo para el caso de los indígenas variaron su criterio. Pero ese modo larvado de construir la jurisprudencia no parece adecuado, pues en este tipo de casos no hay razón alguna para romper la igualdad ante la ley, debiendo dar el mismo trato jurisprudencial a todos los ciudadanos.

En cuanto a una política pública jurisdiccional que enfrente los zigzagueos o vacilaciones de la jurisprudencia, se puede señalar que:

vii) Todo lo anterior es de una relevancia superlativa en cualquier consideración de políticas públicas jurisdiccionales, lo cual no sólo debe ser preocupación de los gobiernos, de los académicos o de los cen- 
tros de pensamiento, sino que también del máximo órgano de la justicia de nuestro país: la Corte Suprema en pleno. Los jueces aportan a nuestra democracia no sólo el valor social de la pacificación a través de cada sentencia, sino que además la certeza en la adjudicación del derecho, y ello pareciera que sólo es posible, adicionalmente, a través de una cultura de precedentes.

\section{ANEXO: SENTENCIAS ANALIZADAS}

Este anexo contiene listados exhaustivos de todas las sentencias de casación emitidas por la Corte Suprema sobre la materia. ${ }^{45}$ (Notas entre corchetes).

9.1. Casos de línea jurisprudencial uniforme desde 2004 a julio 2014 (que acepta suma de posesiones en regularización de derechos de aguas) [15 casos]

- "Comunidad Atacameña Toconce con Essan". Corte Suprema, 22 de marzo de 2004. Rol n. ${ }^{\circ}$ 986-2003. Cuarta Sala. Ministros: Benquis, Álvarez, Marín (redactor), Medina; abogado integrante: Carrasco. [Caso indígena, relevante].

— "Espinoza con Endesa". Corte Suprema, 27 de abril de 2005. Rol n. ${ }^{\circ}$ 1084-04. Cuarta Sala. Ministros: Marín (redactor), Benquis, Pérez, Álvarez y Medina. [Caso relevante].

— "Carbone Salinas con Comunidad de aguas Canal de Azapa". Corte Suprema, 30 de noviembre de 2006. Rol n. ${ }^{\circ} 4157-2005$. Tercera Sala. Ministros: Juica, Gálvez (voto disidente) y Fiscal Judicial Maldonado (voto disidente); abogados integrantes: Álvarez y Castro (redactor). [Votos disidentes no se relacionan con la suma de posesiones].

— "Agrícola Victoria S.A con Endesa". Corte Suprema, 27 de diciembre de 2007. Rol n. ${ }^{\circ}$ 5342-06. Tercera sala. Ministros: Gálvez, Carreño, Araneda (redactora); abogados integrantes: Castro y Gómez. [Sigue texto de sentencia "Espinoza con Endesa" (2005)].

— "Sociedad Agrícola Forestal los Olivos Ltda. con DGA". Corte Suprema, 30 de julio de 2009. Rol n. ${ }^{\circ}$ 313-2008. Tercera Sala. Minis-

${ }^{45}$ Esta jurisprudencia es posible revisarla en: www.poderjudicial.cl o en www. thomsonreuters.cl. 
tros: Brito, Carreño, Oyarzún, Araneda; abogado integrante: Chaigneau (redactor).

- "Agua Mineral Chusmiza S.A.I.C. con Comunidad Indígena Aymara de Chusmiza Usmagama". Corte Suprema, 25 de noviembre de 2009. Rol n. ${ }^{\circ}$ 2840-2008. Segunda Sala. Ministros: Segura, Rodríguez (redactor), Ballesteros y Dolmestch; abogado integrante: Bates. [cita doctrina: Vergara (1998)] [Caso indígena, relevante].

- "Garrido Aedo, Luis Alberto con DOH". Corte Suprema, 12 de mayo de 2011. Rol n. ${ }^{\circ}$ 7410-2008. Segunda Sala. Ministros: Rodríguez, Ballesteros, Dolmestch y Künsemüller; abogado integrante: Chaigneau (redactor).

- "Sociedad Agrícola Pangue con DGA". Corte Suprema, 28 de julio de 2011. Rol n. ${ }^{\circ} 1689$ 2009. Segunda Sala. Ministros: Rodríguez, Ballesteros, Dolmestch (redactor); abogados integrantes Bates y Lagos.

- "AES Gener con DGA". Corte Suprema, 18 de agosto de 2011. Rol n. ${ }^{\circ}$ 654-2009. Segunda Sala. Ministros: Segura, Rodríguez (redactor), Ballesteros, Dolmestch y Künsemüller. [Citas precedentes: "Toconce con Essan" (2003) y "Garrido Aedo con DOH" (2008); cita doctrina: Vergara (1998); cita relevante: dictamen CGR n. ${ }^{\circ}$ 1408-92].

— "Junta de Vecinos La Vega de Cabildo con Oyanedel Araya, Amador". Corte Suprema, 10 de septiembre de 2012. Rol n. 37284 2012. Segunda Sala. Ministros: Juica, Dolmestch, Künsemüller, Brito (redactor) y abogado integrante Bates.

- "Agrícola Santa Lucía Ranch Limitada con Endesa". Corte Suprema, 10 de diciembre de 2012. Rol n. ${ }^{\circ}$ 2315-2011. Primera Sala. Ministros: Segura, Araya, Silva y Maggi; abogado integrante: Prieto (redactor)

— "Sucesión Pastén Huerta con DGA". Corte Suprema, 27 de marzo de 2013. Rol n. ${ }^{\circ}$ 7381-2011. Primera Sala. Ministros: Segura, Araya, Silva, Fuentes; abogado integrante: Vial del Río (redactor).

— "Sociedad Agrícola el Piedrero con Endesa". Corte Suprema, 26 de agosto de 2013. Rol n. ${ }^{\circ}$ 1442-2012. Primera Sala. Ministros: Segura (redactor), Silva, Araya; abogados integrantes: Prieto y Lecaros Zegers. [Sentencia redactada con gran detalle; cita doctrina: Muñoz Escudero (2011); caso relevante].

- "Empresa Eléctrica del Norte Grande con Empresa de Aguas del Altiplano". Corte Suprema, 2 septiembre de 2013. Rol n. ${ }^{\circ} 9197-$ 
2011. Primera Sala. Ministros: Segura, Araya, Silva, Maggi; abogado integrante: Lagos (redactor). [Cita y sigue precedentes: "Toconce" (2004), “Agrícola Victoria” (2007), "Garrido Aedo” (2008) y “AES Gener” (2009); cita doctrina: Muñoz Escudero (2011)].

- "Development and Contracting Company S.A. con DGA". Corte Suprema, 14 de julio de 2014. Rol n. ${ }^{\circ}$ 17241-2013. Tercera Sala. Ministros: Carreño (redactor), Ballesteros, Sandoval; abogados integrantes: Baraona y Bates. [La sentencia rechaza la regularización por falta de prueba, pero acepta la suma de posesión (por esa razón no se considera en gráfico 4); cita caso anterior: "Norte Grande con Altiplano" (2013); cita doctrina: Muñoz Escudero (2011)].

\subsection{Sentencias del giro jurisprudencial desde diciembre 2014 a agosto 2018 (que rechazan la suma de posesiones en regularización de derechos de aguas) [18 casos]}

- "Inversiones de la Cerda Olivo Limitada con Endesa". Corte Suprema, 4 de diciembre de 2014. Rol n. ${ }^{\circ}$ 16578-2014. Tercera Sala. Ministros: Ballesteros, Pierry, Sandoval; abogados integrantes: Bates, Piedrabuena (redactor). [Caso relevante].

— "Inversiones y Asesorías FTM Limitada con Endesa". Corte Suprema, 9 de noviembre de 2015. Rol n. ${ }^{\circ}$ 996-2015. Tercera Sala. Ministros: Sandoval, Egnem (voto disidente), Pierry; abogados integrantes: Prado (redactor) y Quintanilla.

— "Vidal González, Francisco con Endesa". Corte Suprema, 10 de diciembre de 2015. Rol n. ${ }^{\circ}$ 6339-2015. Tercera Sala. Ministros Sandoval, Silva, Aránguiz, Pierry; abogado integrante: Pizarro (redactor).

— "Rojas Gil con Dirección General de Aguas". Corte Suprema, 11 de enero de 2016.- Rol n. ${ }^{\circ}$ 13706-2015. Tercera Sala. Ministros: Sandoval, Egnem (voto disidente), Pierry (redactor); abogados integrantes: Prado, Quintanilla.

- "Agrícola Alianza S.A. con Endesa". Corte Suprema, 12 de enero de 2016, Rol n. ${ }^{\circ}$ 10769-2015. Tercera Sala. Ministros: Sandoval, Aránguiz, Egnem (voto disidente), Valderrama; abogado integrante: Pizarro (redactor).

— "Rivera Cerda, Miguel con Endesa". Corte Suprema, 28 de enero de 2016. Rol n. ${ }^{\circ}$ 10.293-2015. Tercera Sala. Ministros: Sandoval, 
Aránguiz (redactor), Egnem (voto disidente); Pierry; abogado integrante: Rodríguez.

- "Puerto Terrestre Los Andes Sociedad Concesionaria Limitada con DGA". Corte Suprema, 14 marzo 2016. Rol n. ${ }^{\circ}$ 19.686-2015. Tercera Sala. Ministros: Pierry, Sandoval (redactora), Aránguiz, Dahm; abogado integrante: Prado.

- "Agrícola UAC Limitada con Guggiana Femenías, Raúl y otra". Corte Suprema, 5 de julio de 2016. Rol n. ${ }^{\circ}$ 15553-2015. Tercera Sala. Ministros: Sandoval, Aránguiz, Egnem (redactor y voto disidente), Pierry; abogado integrante: Quintanilla.

- "Agrícola y Comercial El Mirador S.A. con DGA". Corte Suprema, 6 de julio de 2016. Rol n. ${ }^{\circ} 10582$ 2015. Tercera Sala. Ministros: Aránguiz, Egnem (voto disidente y redactora), Valderrama; abogados integrantes: Lagos y Gómez (voto disidente).

— "Agrícola San Vicente Limitada con DGA". Corte Suprema, 21 de julio de 2016. Rol n. ${ }^{\circ}$ 3.974-2015. Tercera Sala. Ministros: Sandoval, Aránguiz, Pierry; abogados integrantes: Prado y Matus (redactor).

- "Sociedad Agrícola La Italiana Limitada con DGA". Corte Suprema, 25 de julio de 2016. Rol n. ${ }^{\circ}$ 188-2016. Tercera Sala. Ministros: Sandoval, Aránguiz, Pierry, Egnem (voto disidente y redactora); abogado integrante: Quintanilla.

- "Pérez Ulloa, Cecilia con DGA". Corte Suprema, 24 de noviembre de 2016. Rol n. ${ }^{o}$ 47.597-2016. Tercera Sala. Ministros: Sandoval, Aránguiz, Egnem (voto disidente), Muñoz (voto disidente); abogado integrante: Quintanilla (redactor).

- "Amenábar Vives, Arturo con DGA". Corte Suprema, 29 de noviembre de 2016. Rol n. ${ }^{\circ}$ 17.089-2016. Tercera Sala. Ministros: Sandoval, Aránguiz, Egnem (redactora y voto disidente), Valderrama; abogado integrante: Lagos (voto disidente).

- "Syngenta S.A. con Aguas del Altiplano S.A.”. Corte Suprema, 9 de enero de 2017. Rol n. ${ }^{\circ}$ 65.410-2016. Tercera Sala. Ministros: Muñoz (prevención/disidencia), Sandoval, Valderrama; abogados integrantes: Lagos, Figueroa (redactor).

- "Chambe Salas, Elvira con Aguas del Altiplano". Corte Suprema, 22 de mayo de 2017. Rol n. 38826 2016. Tercera Sala. Ministros: Sandoval, Aránguiz, Egnem (voto disidente) y Muñoz (voto disidente); abogado integrante: Rodríguez (redactor). 
— "Medina Maturana, Mario con DGA". Corte Suprema, 12 de octubre de 2017. Rol n. ${ }^{\circ}$ 2916-2017. Tercera Sala. Ministros: Cerda, Muñoz, Valderrama (redactor); abogados integrantes: Lagos y Matus.

— “Zúñiga Lara, Marcela con DGA”. Corte Suprema, 27 de diciembre de 2017. Rol n. ${ }^{\circ}$ 19124-2017. Tercera Sala. Ministros: Aránguiz, Brito, Egnem, Sandoval y Prado (redactor).

— "Soto Valdivia, Juan con Junta de Vigilancia del río Maule". Corte Suprema, 10 de mayo de 2018. Rol n. ${ }^{\circ}$ 35.661-2017. Tercera Sala. Ministros: Egnem (disidente), Prado (disidente), Sandoval. Abogados integrantes: Pizarro (redactor) y Rodríguez.

\subsection{Sentencias de 2016 a 2018 que aceptan suma de posesiones, y} que, de manera paralela a la nueva tendencia de las sentencias (9.2.), mantienen criterio tradicional de las sentencias (9.1.) [5 casos]

— "Sociedad Agrícola El Porvenir S.A. con DGA". Corte Suprema, 26 de abril de 2016. Rol n. ${ }^{\circ}$ 37109-2015. Primera Sala de febrero. Ministros: Carreño, Pierry (redactor y voto disidente), Silva, Egnem; abogado integrante: Gómez (voto disidente). [Sigue caso "Norte Grande con Altiplano" (2013); cita doctrina: Muñoz Escudero (2011); voto disidente cita los seis casos de 2014 y 2015 de la línea jurisprudencial paralela, y dice: "lo sostenido en las motivaciones anteriores por esta disidencia ha sido el criterio invariable que ha adoptado la Tercera Sala de esta Corte"; voto disidente cita erróneamente el caso "Minera RNC" (2014) como inicio de la nueva línea, pero en aquel caso el rechazo de la regularización fue por falta de prueba de la posesión. La nueva línea, en realidad, se inició en "Inversiones de la Cerda" (2014)].

— "Díaz Farías Luis y otros con Comunidad Indígena de Mulluri. Corte Suprema, 6 de junio de 2017. Rol n. ${ }^{\circ}$ 45848-2016. Tercera Sala. Ministros: Sandoval, Aránguiz (redactor), Muñoz, Valderrama; abogado integrante: Quintanilla. [Cita los casos “Espinoza con Endesa” (2005) y "Agrícola Victoria con Endesa" (2007) y "Chusmiza" (2009); caso indígena]

- "Vera Urra, Patricio con DGA". Corte Suprema, 25 de septiembre de 2017. Rol n. ${ }^{\circ}$ 95094-2016. Tercera Sala. Ministros: Sandoval (voto disidente), Aránguiz (voto disidente), Egnem y Muñoz; abogado integrante: Prado (redactor). [Cita doctrina: Muñoz Escudero (2011); caso relevante]. 
— "Matta Pacheco, Olga con Aguas del Altiplano S.A.". Corte Suprema, 28 de diciembre de 2017. Rol n. ${ }^{\circ}$ 36354-2017. Tercera Sala. Ministros: Egnem, Fuentes, Muñoz; abogados integrantes: Quintanilla (redactor) y Lagos. [Cita doctrina: Muñoz Escudero (2011)].

— "Comunidad Indígena Atacameña de Toconce con Soquimich, SQM, y otros". Corte Suprema, 2 de agosto de 2018. Rol n. ${ }^{\circ} 44.255-$ 2017. Tercera Sala. Ministros: Sandoval (redactora), Muñoz (prevención) y Prado (voto disidente); abogados integrantes: Quintanilla y Matus. [Cita los casos "Espinoza" (2005) y "Agrícola Victoria" (2007)]

\subsection{Casos en que se rechaza la regularización por una razón} distinta a la suma de posesiones: por no ser concluyente la prueba de uso efectivo y otros [ 3 casos]

— "Development and Contracting Company S.A. con DGA". Corte Suprema, 14 de julio de 2014. [Citado al final de 9.1].

- "Minera RMC Las Barracas S.A. con DGA". Corte Suprema, 31 de julio de 2014. Rol n. ${ }^{\circ}$ 2727-2014. Tercera Sala. Ministros: Ballesteros, Carreño, Pierry, Egnem (redactora) y Sandoval. [Casación].

- "Syngenta S.A. con Aguas del Altiplano S.A.". Corte Suprema, 9 de enero de 2017. Rol n. ${ }^{\circ}$ 65.410-2016. Tercera Sala. Ministros: Muñoz (prevención/disidencia), Sandoval, Valderrama; abogados integrantes: Lagos, Figueroa (redactor). [Casación; ministro Muñoz previene que sólo rechaza regularización por falta de prueba de uso y no por doctrina del resto de la sala].

\subsection{Casos de regularización de derechos de comunidades indígenas o en que éstas son parte [4 casos]}

- "Comunidad Atacameña Toconce con Essan". Corte Suprema, 22 de marzo de 2004. [Citado en sección 9.1].

- "Agua Mineral Chusmiza S.A.I.C. con Comunidad Indígena Aymara de Chusmiza Usmagama". Corte Suprema, 25 de noviembre de 2009. [Citado supra en 9.1].

— "Díaz Farías Luis y otros con Comunidad Indígena de Mulluri". Corte Suprema, 6 de junio de 2017. [Citado en sección 9.3].

- "Comunidad Indígena Atacameña de Toconce con Soquimich, SQM, y otros". Corte Suprema, 2 de agosto de 2018. [Citado en sección 9.3]. 


\subsection{Cuadro de redactores de sentencias de suma de posesiones en la regularización de derechos de aguas}

\begin{tabular}{|c|c|c|c|c|c|}
\hline Año & Sala & Causa & Redactor & Acepta & Rechazo \\
\hline 2004 & 4 ta & Toconce con Essan & Urbano Marin & $\sqrt{ }$ & \\
\hline 2005 & 4 ta & Espinoza con Endesa & Urbano Marín & $\sqrt{ }$ & \\
\hline 2006 & $3 a$ & $\begin{array}{l}\text { Carbone S. con } \\
\text { Comunidad Aguas Azapa }\end{array}$ & Fernando Castro (Al) & $\sqrt{ }$ & \\
\hline 2007 & $3 a$ & $\begin{array}{l}\text { Agricola Victoria con } \\
\text { Endesa }\end{array}$ & Sonia Araneda & $\sqrt{ }$ & \\
\hline 2009 & $3 a$ & $\begin{array}{l}\text { Forestal Los Olivos con } \\
\text { DGA }\end{array}$ & $\begin{array}{l}\text { Alberto Chaigneau } \\
\text { (Al) }\end{array}$ & $\sqrt{ }$ & \\
\hline 2009 & $2 a$ & $\begin{array}{l}\text { Agua Mineral Chusmiza } \\
\text { con Comunidad Indigena } \\
\text { Aymara de Chusmiza } \\
\text { Usmagama }\end{array}$ & Jaime Rodriguez & $\sqrt{ }$ & \\
\hline 2011 & $2 a$ & Garrido Aedo con DOH & Alberto Chaigneau & $\sqrt{ }$ & \\
\hline 2011 & $2 a$ & Soc. Agricola Pangue & Hugo Dolmestch & $\sqrt{ }$ & \\
\hline 2011 & $2 a$ & Aes Gener con DGA & Jaime Rodriguez & $\sqrt{ }$ & \\
\hline 2012 & $2 a$ & $\begin{array}{l}\text { Junta de Vecinos La Vega } \\
\text { Cabildo con Oyanedel }\end{array}$ & Haroldo Brito & $\sqrt{ }$ & \\
\hline 2012 & la & $\begin{array}{l}\text { Agricola Sta. Lucia con } \\
\text { Endesa }\end{array}$ & Alfredo Prieto (Al) & $\sqrt{ }$ & \\
\hline 2013 & la & $\begin{array}{l}\text { Sucesión Pastén Huerta } \\
\text { con DGA }\end{array}$ & Victor Vial del Rio (Al) & $\sqrt{ }$ & \\
\hline 2013 & la & $\begin{array}{l}\text { Soc. Agricola El Piedrero } \\
\text { con Endesa }\end{array}$ & Nibaldo Segura & $\sqrt{ }$ & \\
\hline 2013 & la & $\begin{array}{l}\text { Empresa Eléctrica del } \\
\text { Norte Grande con Aguas } \\
\text { del Altiplano }\end{array}$ & Jorge Lagos (Al) & $\sqrt{ }$ & \\
\hline 2014 & $3 a$ & $\begin{array}{l}\text { Development and } \\
\text { Contracting Company con } \\
\text { DGA }\end{array}$ & Héctor Carreño & $\sqrt{ }$ & \\
\hline 2014 & $3 a$ & $\begin{array}{l}\text { Inversiones de la Cerda } \\
\text { con Endesa }\end{array}$ & $\begin{array}{c}\text { Guillermo } \\
\text { Piedrabuena (Al) }\end{array}$ & & $x$ \\
\hline 2015 & $3 a$ & $\begin{array}{l}\text { Inversiones FTM con } \\
\text { Endesa }\end{array}$ & Arturo Prado (Al) & & $x$ \\
\hline 2015 & $3 a$ & Vidal González con Endesa & Carlos Pizarro (Al) & & $x$ \\
\hline 2016 & $3 a$ & Rojas Gil con DGA & Pedro Pierry & & $x$ \\
\hline 2016 & $3 a$ & Agrícola Alianza & Carlos Pizarro (Al) & & $x$ \\
\hline 2016 & $3 a$ & Rivera Cerda con Endesa & Carlos Aránguiz & & $x$ \\
\hline 2016 & $3 a$ & $\begin{array}{l}\text { Puerto Terrestre Los } \\
\text { Andes con DGA }\end{array}$ & $\begin{array}{l}\text { Maria Eugenia } \\
\text { Sandoval }\end{array}$ & & $x$ \\
\hline
\end{tabular}




\begin{tabular}{|c|c|c|c|c|c|}
\hline Año & Sala & Causa & Redactor & Acepta & Rechaza \\
\hline 2016 & la feb & $\begin{array}{l}\text { Sociedad Agrícola El } \\
\text { Porvenir con DGA }\end{array}$ & Pedro Pierry & & $x$ \\
\hline 2016 & $3 a$ & $\begin{array}{l}\text { Agricola UAC con } \\
\text { Gugggiana Femenías, Raúl }\end{array}$ & Rosa Egnem & $\sqrt{ }$ & \\
\hline 2016 & $3 a$ & $\begin{array}{l}\text { Agricola El Mirador con } \\
\text { DGA }\end{array}$ & Rosa Egnem & $\sqrt{ }$ & \\
\hline 2016 & $3 a$ & $\begin{array}{l}\text { Agricola San Vicente con } \\
\text { DGA }\end{array}$ & $\begin{array}{l}\text { Jean Pierre Matus } \\
\text { (Al) }\end{array}$ & & $x$ \\
\hline 2016 & $3 a$ & $\begin{array}{l}\text { Agricola La Italiana con } \\
\text { DGA }\end{array}$ & Rosa Egnem & $\sqrt{ }$ & \\
\hline 2016 & $3 a$ & $\begin{array}{l}\text { Pérez Ulloa, Cecilia con } \\
\text { DGA }\end{array}$ & $\begin{array}{l}\text { Álvaro Quintanilla } \\
\text { (Al) }\end{array}$ & & $x$ \\
\hline 2016 & $3 a$ & $\begin{array}{l}\text { Amenábar Vives, Arturo } \\
\text { con DGA }\end{array}$ & Rosa Egnem & $\sqrt{ }$ & \\
\hline 2017 & $3 a$ & $\begin{array}{l}\text { Syngenta con Aguas del } \\
\text { Altiplano }\end{array}$ & Juan Figueroa (Al) & & $x$ \\
\hline 2017 & $3 a$ & $\begin{array}{l}\text { Chambe Salas, Elvira con } \\
\text { Aguas del Altiplano }\end{array}$ & Jaime Rodríguez (Al) & & $x$ \\
\hline 2017 & $3 a$ & $\begin{array}{l}\text { Luis Diaz Farias con } \\
\text { Comunidad Indigena } \\
\text { Mulluri }\end{array}$ & Carlos Aránguiz & $\sqrt{ }$ & \\
\hline 2017 & $3 a$ & $\begin{array}{l}\text { Medina Maturana, Mario } \\
\text { con DGA }\end{array}$ & Manuel Valderrama & & $x$ \\
\hline 2017 & $3 a$ & $\begin{array}{l}\text { Vera Urra, Patricio con } \\
\text { DGA }\end{array}$ & Arturo Prado & $\sqrt{ }$ & \\
\hline 2017 & $3 a$ & $\begin{array}{l}\text { Matta Pacheco, Olga con } \\
\text { Aguas del Altiplano }\end{array}$ & Álvaro Quintanilla (Al) & $\sqrt{ }$ & \\
\hline 2017 & $3 a$ & $\begin{array}{l}\text { Zúñiga Lara, Marcela con } \\
\text { DGA }\end{array}$ & Arturo Prado & & $x$ \\
\hline 2018 & $3 a$ & $\begin{array}{l}\text { Soto Valdivia, Juan y otra } \\
\text { con Junta de Vigilancia } \\
\text { Rio Maule }\end{array}$ & Pizarro Wilson (Al) & & $x$ \\
\hline 2018 & $3 a$ & $\begin{array}{l}\text { Comunidad Indigena } \\
\text { Atacameña de Toconce } \\
\text { con SOM S.A. }\end{array}$ & $\begin{array}{l}\text { Maria Eugenia } \\
\text { Sandoval }\end{array}$ & $\sqrt{ }$ & \\
\hline
\end{tabular}




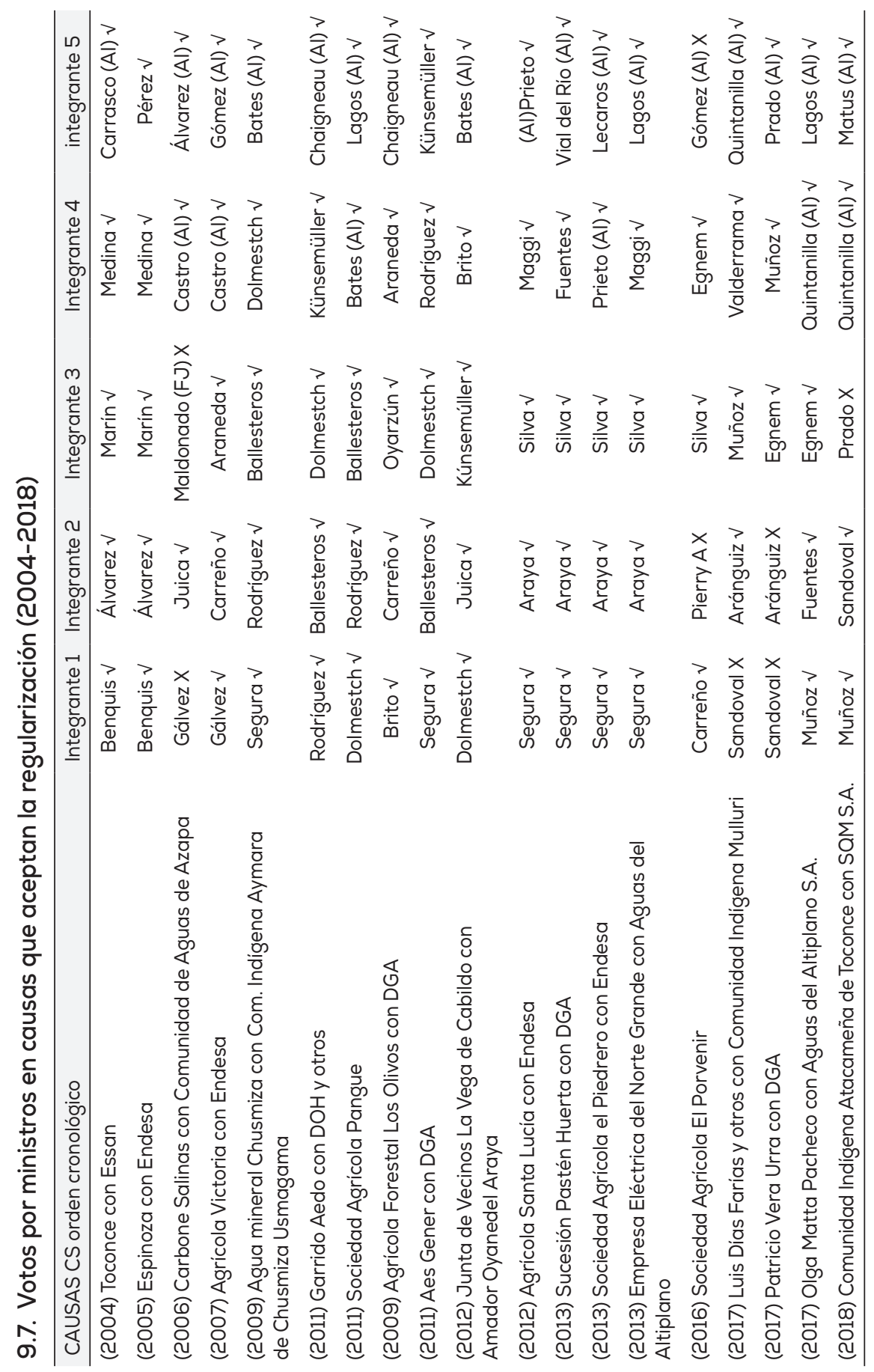




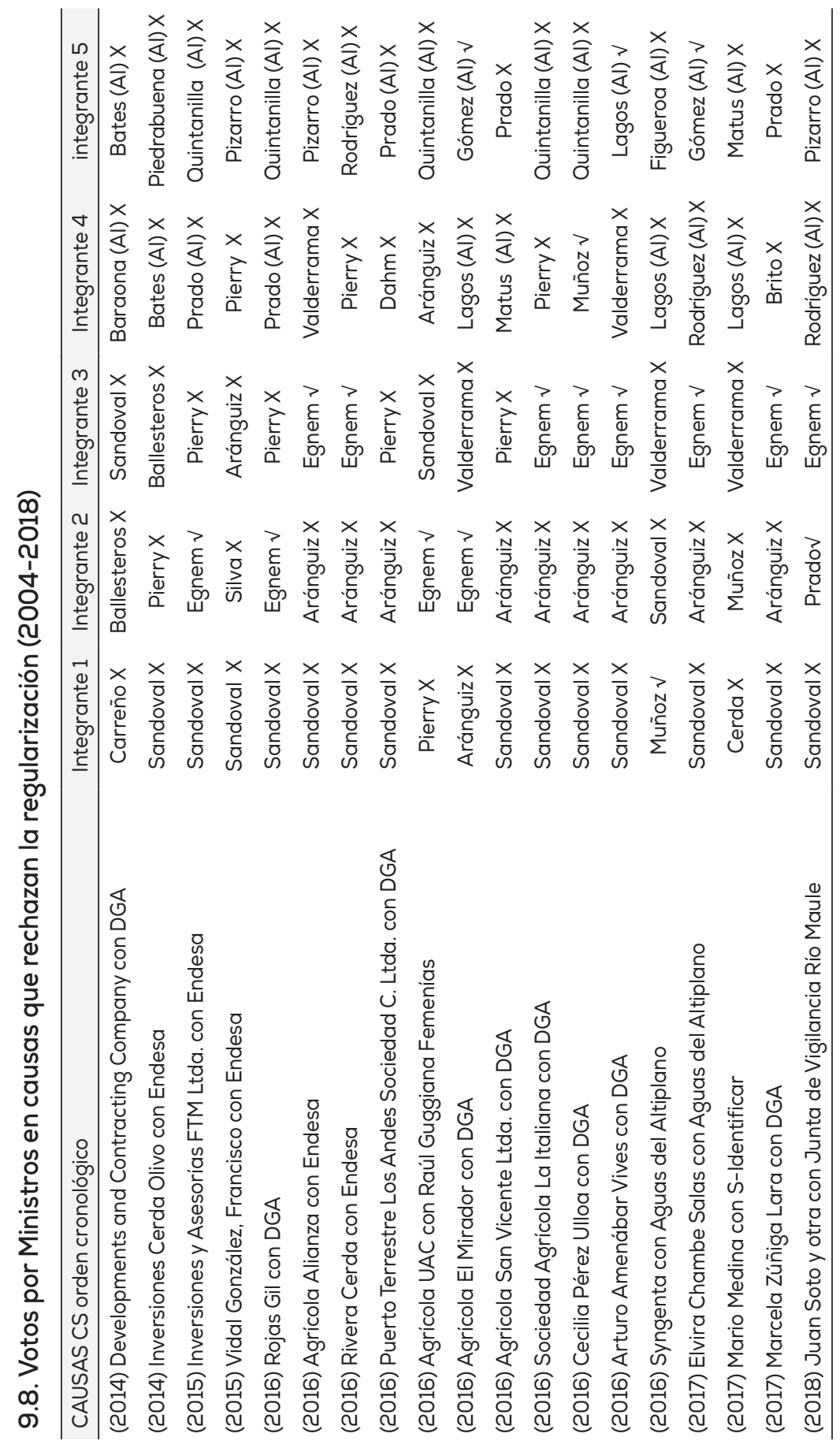




\section{BIBLIOGRAFÍA}

Alessandri Rodríguez, Arturo y Manuel Somarriva Undurraga. Curso de derecho civil. Los bienes y los derechos reales (Santiago: Editorial Nascimento, 1974).

Banco Mundial. Diagnóstico de la gestión de los recursos hídricos. Santiago. Documento del Banco Mundial, Departamento de Medio Ambiente y Desarrollo Sostenible Región para América Latina y el Caribe. 2011.

Bronfman, Alan. "La división de las leyes". En La técnica legislativa ante la elaboración de la ley, 186-190. Valparaíso: Centro de Estudios y Asistencia Legislativa, Universidad de Valparaíso, 1998.

CIDH. Informe anual, capítulo IV. A: “Acceso al agua en las Américas. Una aproximación al derecho humano al agua en el sistema interamericano". 2015. http://www.oas.org/es/cidh/docs/anual/2015/doces/InformeAnual2015-cap4Aagua-ES.pdf/.

Cuadra, Manuel. "Los derechos de agua de propiedad ancestral de las comunidades atacameñas del Norte de Chile". Revista de Derecho Administrativo Económico 2, n. ${ }^{\circ} 1$ (2000): 85-94.

Dirección General de Aguas. Instructivo artículo 2 transitorio del Código de Aguas. Ord. n. ${ }^{\circ} 25$ de 5 noviembre 1999, que aprueba Minuta $n .^{\circ} 165$, de 28 de octubre de 1999. Ministerio de Obras Públicas de Chile, 1999.

- Manual de normas y procedimientos para la administración de recursos hídricos. S. I. T. n. ${ }^{\circ}$ 156. Ministerio de Obras Públicas de Chile, 2008.

Epstein, Lee, William Landes \& Richard Posner. "Why (and When) Judges Dissent: A Theoretical and Empirical Analysis". John M. Olin Program in Law and Economics Working Paper 510. 2010.

Éveillard, Gweltaz. Les dispositions transitoires en droit public français (París: Dalloz, 2007).

Figueroa del Río, Luis Simón. Asignación y distribución de las aguas terrestres. Santiago: Universidad Gabriela Mistral, 1995.

Héron, Jacques. Principes du droit transitoire. París: Dalloz, 1996.

Muñoz, Gonzalo. "Problemas que plantean las regularizaciones de derechos de aprovechamiento de aguas". Revista de Derecho Administrativo Económico 3, n. ${ }^{\circ} 2$ (2001): 565-576.

- "Regularización de derechos de aprovechamiento de aguas". En Código de Aguas comentado. Santiago: Abeledo Perrot, 2011.

Muñoz, Rodrigo. “Aguas indígenas: Categoría excepcional”. Revista de Derecho Administrativo Económico 3, n. ${ }^{\circ} 2$ (2000): 425-428.

Neumann, Christian. "Del procedimiento especial de regularización de derechos de aprovechamiento de aguas conforme al artículo $2^{\circ}$ transitorio del Código de Aguas". Revista de Derecho Administrativo Económico 2, n. ${ }^{\circ}$ (2000): 211 246.

Pardow, Diego \& Flavia Carbonell. "Buscando al juez mediano: estudio sobre la formación de coaliciones en la Tercera Sala de la Corte Suprema". Revista de Ciencia Política (2018, en prensa). 
Rivera, Daniela. Usos y derechos consuetudinarios de aguas. Su reconocimiento, subsistencia y ajuste. Santiago: Thomson Reuters, 2013.

Savigny, Karl Friedrich von. Das Recht des Besitzes. Eine Civilistiche Abhandlung [El derecho de posesión. Una monografía civilista], 1803.

Sunstein, Cass R. After the Rights Revolution: Reconceiving The Regulatory State. Cambridge: Harvard University Press, 1990.

Vergara, Alejandro. Crisis institucional del agua. Descripción del modelo jurídico, crítica a la burocracia y necesidad de tribunales especiales. Santiago: Ediciones UC, 2015.

—. Derecho de aguas. Santiago: Editorial Jurídica de Chile, 1998.

Derecho de aguas: Identidad y transformaciones. Santiago: Ediciones UC, 2017.

- Diagnóstico de problemas en la gestión de recursos hídricos: aspectos institucionales para una futura propuesta de modificaciones legales, reglamentarias y/o de prácticas administrativas. Informe preparado para el diagnóstico de la gestión de los recursos hídricos: Santiago: Banco Mundial, 2010 .

- "Estatuto jurídico, tipología y problemas actuales de los derechos de aprovechamiento de aguas. En especial, de su regularización y catastro". Estudios Públicos 69 (1998): 155-205.

- "Formación de la ley y técnica legislativa". En Diagnóstico histórico jurídico del Poder Legislativo en Chile: 1960-1990, 189-192. Valparaíso: Centro de Estudios y Asistencia Legislativa, Universidad de Valparaíso, 1993. También publicado en Revista Chilena de Derecho 18, n. ${ }^{\circ} 2$ (1993).

"El mercado de aguas en el derecho chileno. Titularidades privadas y libertad de transacción”. En Precios y mercados del agua. Madrid: Editorial Civitas, 1996.

- "Reconocimiento de usos consuetudinarios de aguas". En Código de Aguas comentado. Santiago, Abeledo Perrot, 2011. XXI-XXII.

- "Regularización de derechos de aguas y publicidad en el uso de las mismas". Revista de Derecho de Aguas 7 (1996): 254-255.

- "Regularización de derechos consuetudinarios de aguas y suma de posesiones en todo derecho real". El Mercurio Legal, 3 febrero de 2016.

_. "Regularización de derechos consuetudinarios de aguas: el valor de la posesión y uso ancestral del agua (parte II)". El Mercurio Legal, 22 febrero de 2017.

—. "Regularización de derechos consuetudinarios de aguas: génesis y efectos de una nueva línea jurisprudencial (parte III)". El Mercurio Legal, 13 abril de 2017.

—_ "Regularización de derechos consuetudinarios de aguas: dispersión jurisprudencial en 2017 (parte IV)”. El Mercurio Legal, 10 enero de 2018.

Viver i Pi-Sunyer, Carles. "La parte final de las leyes". En La forma de las leyes. 10 estudios de técnica legislativa, de Gretel (Grupo de Estudios de Técnica Legislativa), 135-172. Barcelona: Bosch, 1986. EP 